\title{
THEORY INTO PRACTICE: ARISTOTELIAN PRINCIPLES IN ARISTARCHEAN PHILOLOGY
}

\author{
FRANCESCA SCHIRONI
}

$\mathrm{T}$ HE PERIPATETIC INFLUENCE on many of the fields developed at Alexandria is undeniable: chronology, ethnography, paradoxography, glossography, literary biography, and bibliography (pinakes), as well as medicine and mechanics, ${ }^{1}$ owe much to the Aristotelian school and its approach to Wissenschaft. In recent years, against Pfeiffer's refusal to see any link between Aristotle and the Alexandrian grammarians, ${ }^{2}$ scholars like Gallavotti, Nickau, Lührs, Porter, Montanari, Richardson, and Matthaios ${ }^{3}$ have argued in favor of the influence of Aristotle on Alexandrian philology and in particular on Aristarchus' scholarship. Some parallels between Aristotle and Aristarchus can be found in the distinction between Homer and the Cyclic poets; in the idea of the $\tau \dot{\varepsilon} \lambda$ o $\varsigma$ of a work (in particular, the famous statement that the Odyssey had reached its $\tau \dot{\varepsilon} \lambda \mathrm{o} \varsigma$ at 23.296); ${ }^{4}$ in the theory that the Iliad and the Odyssey are creations of one poet, Homer (schol. Il. 5.60a, 11.147a); and in the importance of the principle of consistency (Homer does not contradict himself).

In this paper, I would like to return to this issue, focusing in particular on the intellectual relationship between Aristotle and Aristarchus. Passages from the Rhetoric and above all from the Poetics will be compared to the Aristarchean sources from the Homeric scholia. In order to proceed in my analysis, I will take into account only the scholia maiora to the Iliad and the Odyssey and, among them, only those by Aristonicus and, with more caution, by Didymus. ${ }^{5}$ These, I believe, are the only secure sources for Aristarchean

This is a revised version of a paper that I presented at the APA, in Montreal, January 2006. I would like to thank Richard Janko, who read a first version of this paper, the two anonymous referees of Classical Philology for their comments and suggestions, and Thomas Jenkins for proofreading the final version. Translations are mine unless otherwise noted.

1. A relationship between Aristotle and Alexandrian medicine, both sharing the principle of teleology, has been highlighted by von Staden (1997).

2. Pfeiffer 1968, 67, 87-88, 95, 272. For a criticism of Pfeiffer's view, see in particular Rossi 1976, 110-14; and Montanari, in Montanari 1994, 2, 29-31.

3. Gallavotti 1969; Nickau 1977, 132-83 (on Zenodotus and his analysis of the narrative contradictions); Lührs 1992, 13-17; Porter 1992, esp. 74-80; Montanari 1993, esp. 259-64; Richardson 1993, 35-36; 1994; Matthaios 1999, passim; 2002, 174-77, 189-90; cf. also Podlecki 1969; and Montanari 2001.

4. Cf. Gallavotti 1969 and Erbse 1972, 166-77.

5. As a general principle, all the scholia quoted in the present study are by Aristonicus. I always alert the reader in the few cases when I discuss a scholium by Didymus, a much more independent scholar, who hence is a much less reliable source for Aristarchean material. 
material when the name of the grammarian is not expressly quoted. All the other scholia that do not explicitly mention Aristarchus are excluded in the present work, however "Aristarchean" they may sound. ${ }^{6}$

\section{Some Preliminary Remarks: Aristotle's Theory, Aristarchus' Practice, and the Question of Terminology}

The comparison between Aristotle and in general the Peripatetic school, on the one hand, and Aristarchus and the work done at the Museum, on the other, must be put in the right context, for it is clear that the ethos and essence of the work of Aristotle and that of Aristarchus were fundamentally different. Whereas Aristotle wrote theoretical treatises, Aristarchus did not produce a single speculative work; all his theoretical background must be inferred

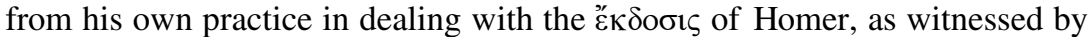
the Homeric scholia. We can thus oppose Aristotle's theory to Aristarchus' practice and see whether and, if so, how this Aristotelian conceptual framework fits Aristarchus' methodology.

As for terminology, many of the same terms are to be found both in Aristotle and Aristarchean scholia. However, in approaching this topic, we must employ caution for various reasons. First, at least with Aristarchus, we are dealing not with his own work, transmitted by direct tradition, but with the scholia by Aristonicus. Though beyond a doubt derived from Aristarchus, these scholia are excerpts of his work, and thus may not necessarily preserve Aristarchus' ipsissima verba. This is especially true for grammatical terminology, since between the time of Aristarchus (third to second century B.C.E.) and that of Aristonicus (first century B.C.E.) grammatical and linguistic analysis developed greatly. Thus Aristonicus had at his disposal a much more precise and extended vocabulary for grammatical categories, and there is evidence that sometimes he rephrased Aristarchus' original Wortlaut in order to update it with the new terminology of the $\tau \dot{\varepsilon} \chi \vee \eta ~ \gamma \rho \alpha \mu \mu \alpha \tau i \kappa \eta{ }^{7}{ }^{7}$ However, for a different kind of vocabulary, that of literary criticism, the situation is different. First, key words used by Aristotle and Aristarchus in

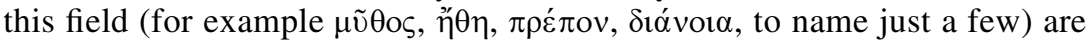
part of a common technical vocabulary, shared by all scholars discussing literary texts (including Crates and the крıєıкоí too; see below) between the fourth and the first centuries B.C.E. Thus, in this field, unlike in the $\tau \varepsilon \dot{\varepsilon} \chi \eta$ $\gamma \rho \alpha \mu \mu \alpha \tau \iota \kappa \eta$, the vocabulary available to Aristonicus was essentially that of Aristotle, and thus that of Aristarchus. When dealing with interpretation and exegesis in a broader sense, therefore, it is much more likely that Aristonicus did not change the Wortlaut he found in Aristarchus' hypomnemata. Moreover, most of the terms in this field are not, strictly speaking, "technical

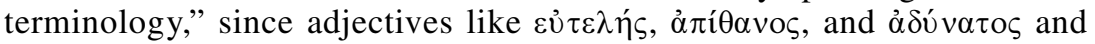

6. Interesting results in the analysis of exegetical scholia (which however are not derived from Aristarchus, and also probably represent a later stage in Homeric criticism) were developed by Schmidt (1976) and by Richardson (1980); see also Montanari 1995.

7. See Matthaios 1999, 43-46, 520-22. 


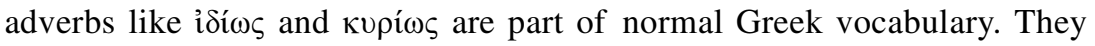
were also used by Aristotle as well as by other Greek authors in literary exegesis, but were not "invented" to express technical notions (as happened for the parts of speech of the $\tau \dot{\varepsilon} \chi \nu \eta \gamma \rho \alpha \mu \mu \alpha \tau \iota \kappa \eta)$. Even if the usage of these more common terms in Aristonicus' scholia does not guarantee that they were exactly the same terms used by Aristarchus, what really matters is not the "form" but rather the "content" of these words, that is, the concept they express. Since Aristonicus' goal was to preserve Aristarchus' opinions concerning a line, what matters most are the ideas Aristonicus conveys. Thus, in what follows, even if Greek nouns and adjectives are used to indicate certain ideas common to Aristotle and Aristarchus (since these terms are to be found in both Aristotle's writings and in Aristonicus' scholia), the focus is rather on the content they convey-Aristarchus' ideas-than on Aristonicus' Wortlaut. ${ }^{8}$ As will become clear, the affinity between Aristotle and Aristarchus is evident in shared ideas and common approaches to literature, and this is the direction and the ultimate goal of the analysis that follows.

\section{A Preliminary Assumption: Tragedy and Epos Are Strictly Connected}

At the beginning of the Poetics (1448b24-1449a6), Aristotle draws a famous distinction between the two main "genres" of poetical works: serious and comic. Among the former he counts tragedy, which, according to him, is derived from the serious epic represented by the Iliad and the Odyssey, just as comedy is derived from the Homeric Margites (Poet. 1448b24-1149a2):

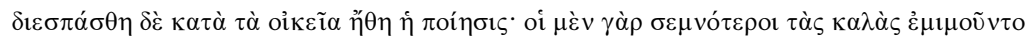

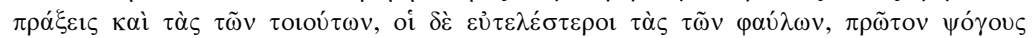

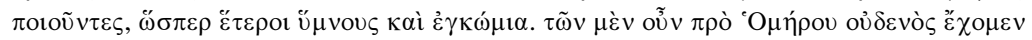

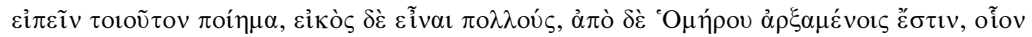

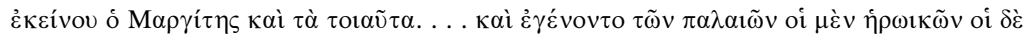

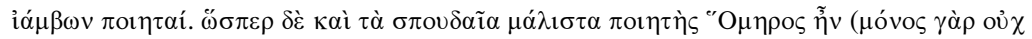

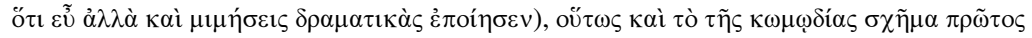

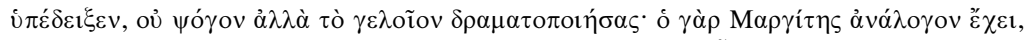

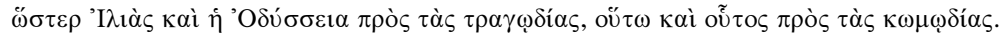

Poetry was split up according to their particular characters; the grander people represented fine actions, i.e. those of fine persons, the more ordinary people represented those of inferior ones, at first composing invectives, just as the others composed hymns and praise-poems. We do not know of any composition of this sort by anyone before Homer, but there were probably many [who composed invectives]. Beginning with Homer [such compositions] do exist, e.g., his Margites etc. . . Thus some of the ancients became composers of heroic poems, others of lampoons. Just as Homer was the greatest composer of serious poetry (not that he alone composed well, but because he alone composed dramatic representations), so too he was first to indicate the form of comedy, by dramatizing not an invective but the laughable. For his Margites stands in the same relation to comedies as do the Iliad and the Odyssey to tragedies. (Trans. Janko 1987)

8. The same point has been made by Lührs $(1992,16)$. 
It is this "etiological" derivation that allows us to look at how Aristarchus analyzes epic poetry in search of Aristotelian criteria, for ultimately these two genres are not so far apart. Aristotle himself emphasizes this (Poet. 1449b16-20):

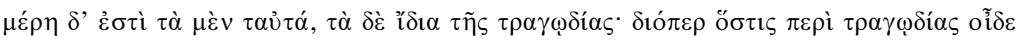

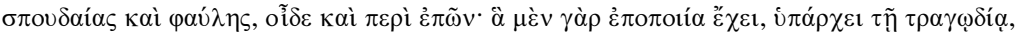

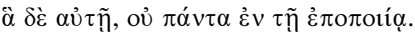

As for their parts, some are the same, others are particular to tragedy. For this reason, whoever knows about good and inferior tragedies knows about epics too. Tragedy possesses all [the parts] that epic has, but those that it possesses are not all in epic. (Trans. Janko 1987)

It is this close relationship between tragedy and epic ${ }^{9}$ that allows for the identification of Aristotelian criteria within the work of a Homeric scholar like Aristarchus. If what I am going to argue is sound, Aristarchus knew what the philosopher had said about the affinity between these two genres and therefore thought it legitimate to apply Aristotle's criteria for a good tragedy to epic poetry. The Alexandrians knew some of the Aristotelian works, and whether or not the Poetics was available to them, the dialogue On Poets, in which Aristotle discussed the same topics as in the Poetics, and the Homeric Problems were both known. ${ }^{10}$

For Aristotle tragedy is composed of six parts (Poet. 1450a9-10): plot

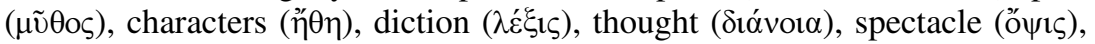
and music ( $\mu \varepsilon \lambda o \pi$ otí $\alpha$ ). In the chapters on epic, he picks up this division again, but rightly states that epic lacks the last two, music and spectacle (Poet. 1459b7-10). ${ }^{11}$ This is a very useful working distinction, which helps Aristotle to set out a systematic view of the main constituents of a tragedy (and of an epos too), as well as to refer to other works such as the Rhetoric for elements that have already been treated elsewhere. This distinction of epic into four elements seems, moreover, to operate also in Aristarchus' methodology, especially when he must decide about an athetesis, for a line is generally judged with reference to its function for the plot, for the characters, for the thought it expresses, and in terms of style. Therefore we will follow this division in our analysis and will see what Aristotle and Aristarchus have to say about the plot, the characters, the thought-element and the style.

9. As proved also by the last chapters of the Poetics (chaps. 23-26), where Aristotle focuses on epic poetry, drawing on the previous chapters where he analyzed tragedy. For an account of Aristotle's views on Homer, see Richardson 1992, and 1993, 31-35.

10. Cf. Nickau 1977, 138-39, with n. 16; Lührs 1992, 14-15, Richardson 1994, 17-18, 27. On the debated problem about the destiny of the library and the books of Aristotle, see Moraux 1973, 3-31; Canfora 1988, 34-37, 59-66; Richardson 1994, 8-12; Nagy 1998, 198-206; Barnes 1999; Canfora 2002. The Poetics in particular does not seem to have enjoyed great popularity in antiquity: ancient soruces are silent, and the earliest quotation is in Porphyry (quoted by Simplicius [in Cat., p. 36.16-31 Kalbfleisch]): see Janko 1982, and 1991, 7 and n. 25.

11. One problem is, of course, assessing whether this difference can be interpreted as a demonstration that tragedy is a more accomplished form of art than epic. However, there are also advantages in the lack of spectacle in the epos: see p. 286 below. 


\section{Aristotelian Theory and Aristarchean Practice: MY $\Theta O \Sigma$}

Since for Aristotle tragedy (and epic too) is an imitation of a complete and

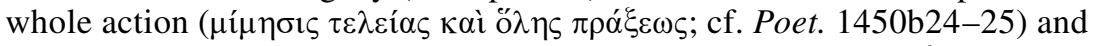

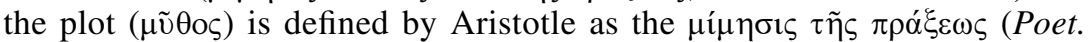
1450a3-4), it follows that the plot is "the principle and as it were the soul

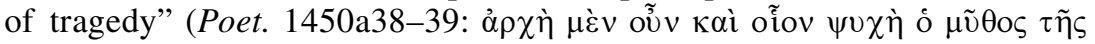
$\tau \rho \alpha \gamma\left(\delta_{i} \alpha \varsigma\right)$. One of the most important criteria for the plot is that it must be in accordance with probability and necessity (Poet. 1451a36-38 and 1451b8-10):

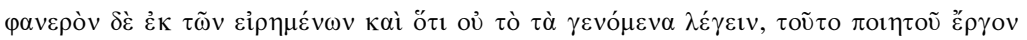

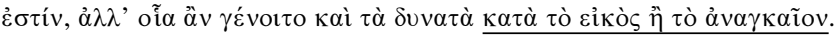

It is also obvious from what we have said that it is the function of a poet to relate not things that have happened, but things that may happen, i.e. that are possible in accordance with probability or necessity. (Trans. Janko 1987)

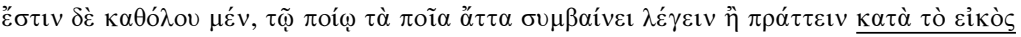

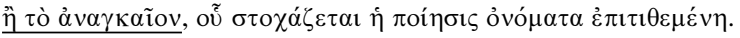

A universal is the sort of thing that a certain kind of person may well say or do in accordance with probability or necessity - this is what poetry aims at, although it assigns names [to the people]. (Trans. Janko 1987)

For Aristotle, then, plots can contain what is "necessary" ( $\dot{\alpha} v a \gamma \kappa \alpha i o v)$, but

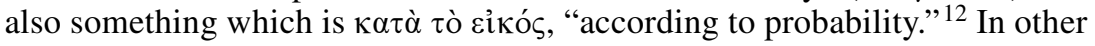
words, a plot must consist of a necessary or probable sequence of events. This is due to the particular status of poetry, which distinguishes it from history: poetry represents universals, not particulars, like history; hence poetry is more philosophical (Poet. 1451b5-7):

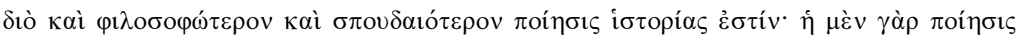

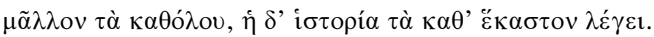

For this reason poetry is a more philosophical and more serious thing than history: poetry tends to speak of universals, history of particulars. (Trans. Janko 1987)

Moreover, in poetry, elements that are impossible in reality are nevertheless admitted because in this way the poet is able to astonish his audience and

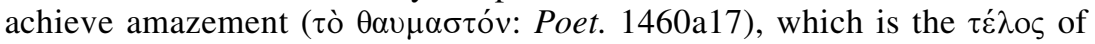
poetry (Poet.1460b23-26):

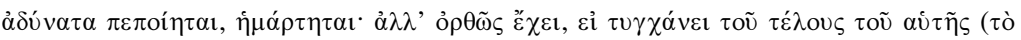

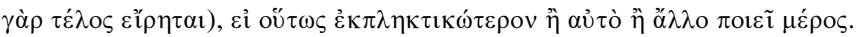

12. The same kind of contrast is found again when Aristotle is dealing with episodic plots, where we

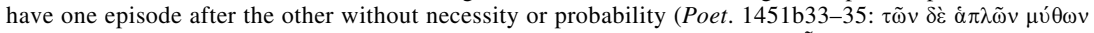

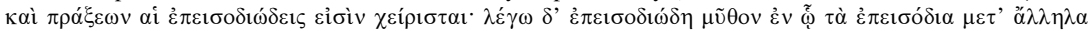

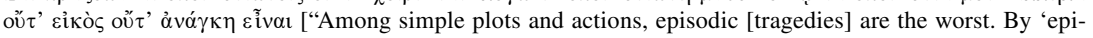
sodic' I mean a plot in which there is neither probability nor necessity that the episodes follow one other," trans. Janko 1987]). 
[If] impossibilities have been produced, there is an error; but it is correct, if it attains the end of the art itself. The end has been stated [already, i.e.] if in this way it makes either that part [of the poem], or another part, more astonishing. (Trans. Janko 1987)

Since supernatural, impossible elements make the poetry more interesting, ${ }^{13}$ Aristotle judges the plot not according to whether it is possible or not,

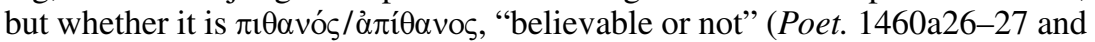
1461b9-12):

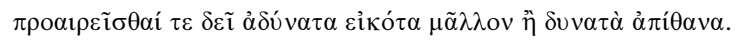

Impossible [incidents] that are believable should be preferred to possible ones that are unbelievable. (Trans. Janko 1987)

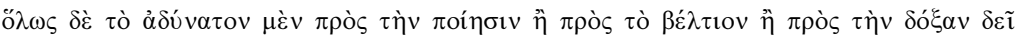

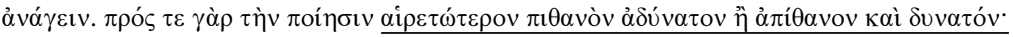

In general, the impossibility should be explained with reference either to the composition, or to [making something] better [than it is], or to opinion. In relation to [the needs of] the composition, a believable impossibility is preferable to an unbelievable possibility. (Trans. Janko 1987)

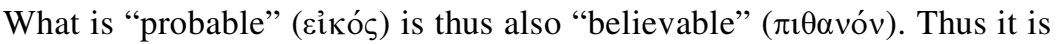
better for Aristotle to choose plots that are believable-though they may not be possible in the real world $(\pi \imath \theta \alpha v \alpha \grave{\alpha} \delta v ́ v \alpha \tau \alpha)$ — than stories that could happen but are not believable ( $\delta v v \alpha \tau \grave{\alpha} \alpha \dot{\alpha} i \dot{\theta} \alpha v \alpha) .{ }^{14}$

Since a poet, in order to achieve $\tau$ ò $\theta \alpha v \mu \alpha \sigma \tau o ́ v$, has more freedom, the criterion of "believability" becomes an internal one: something is believable if it follows from what has been stated before as a logical consequence. Within a work of poetry there are rules that are typical of poetry and, as long as these rules are respected by the poet, the poetic work is good, no matter how the $\mu \tilde{v} \theta 0 \varsigma$ in itself corresponds to truth in the real world. The premise behind these prescriptions is that poetry is a $\tau \varepsilon \chi \nu \eta$ that works according to rules that are its own and different from those of other $\tau \dot{\varepsilon} \chi v \alpha \mathrm{l}$ (Poet. 1460b13-15): ${ }^{15}$

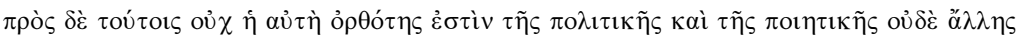

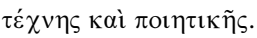

In addition, there is not the same [standard of] correctness in the art of civic life as in that of poetry, nor is there in any other art as in that of poetry. (Trans. Janko 1987)

\subsection{Aristarchus: The Criterion of Believability}

As for Aristotle, so also for Aristarchus, the main criterion for judging the plot is not the distinction between what is possible and what is not, but that

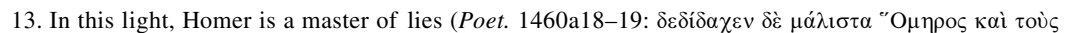

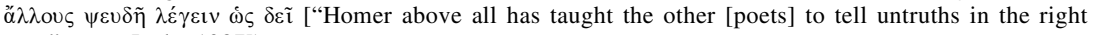
way," trans. Janko 1987]).

14. This is because what is possible is believable, but not all that is believable is possible; hence believ-

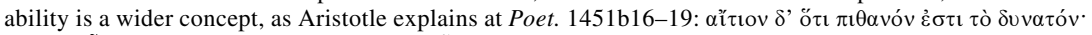

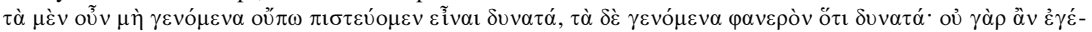

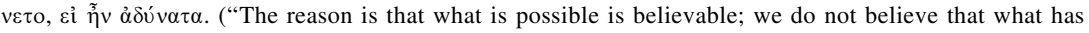
never happened is possible, but things which have happened are obviously possible- they would have not have happened if they were impossible," trans. Janko 1987).

15. Cf. Richardson 1992, 36. 


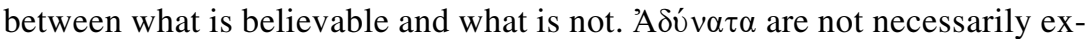
cluded if they help poetic goals. There are only two cases of lines athetized by Aristarchus because they contain $\alpha \delta \delta$ v $v \alpha \alpha$, "impossibilities." The first case is in the Nekyia: ${ }^{16}$ the lines about Otus and Ephialtes' project to put Olympus on Ossa and Pelium on top of them in order to reach the sky (Od. 11.315-16:

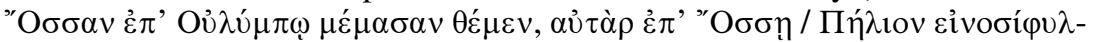

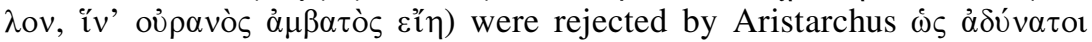
(schol. V Od. 11.315). The other case is at Odyssey 22.144-45, where Melanthius, in order to help the suitors, takes out from the chamber twelve shields, the same number of spears and the same number of helmets, as Eustathius testifies (Eust. Od. 1921.56):

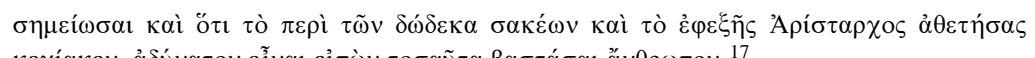

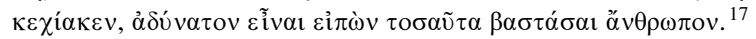

Note also that Aristarchus athetized and marked with a chi the line about the twelve shields and the following one, saying that it was impossible that a person could carry all these [weapons]. ${ }^{18}$

Nevertheless, in the Iliad, for example, there are no cases of athetesis due

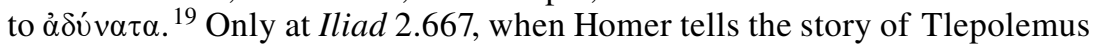
arriving at Rhodes after killing his uncle Licymnius, Zenodotus' reading

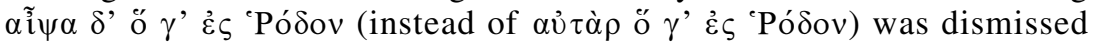
by Aristarchus because it would be impossible for a fugitive wandering in the Aegean to arrive "at once" at Rhodes. ${ }^{20}$ Otherwise, elements that are impossible from a rational point of view are allowed because of poetic license. For example, the fact that the Cyclops knows that ships exist or understands Greek is in itself absurd, but for Aristarchus it is to be kept, because it is poetry (schol. HMQR Od. 3.71):

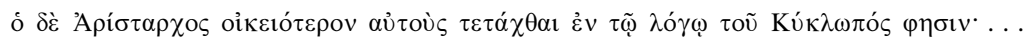

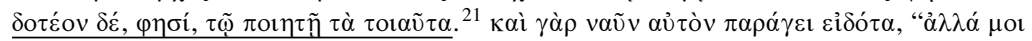

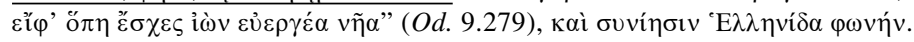

Aristarchus says that these lines are more properly included in the speech of the Cyclops [than here in Telemachus' speech]. .. . But, he says, we must allow these [licenses] to the poet. For Homer represents the Cyclops as aware [of the existence] of a ship, [as it is proved by] "but tell me where, arriving, you put your well-made ship" (Od. 9.279), and [the Cyclops] understands the Greek language.

16. An episode that was particularly suspicious to Aristarchus; see p. 288 below.

17. Eustathius is here probably quoting Aristonicus (see Carnuth 1869, ad loc.) from a collection of scholia richer than the one that has reached us (and which does not present any scholium on Od. 22.144-45).

18. The possibility that Melanthius might have carried all these weapons in more than one journey does not seem to have been taken into consideration by Aristarchus.

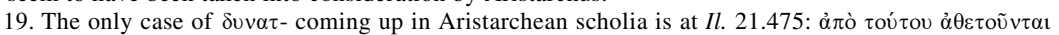

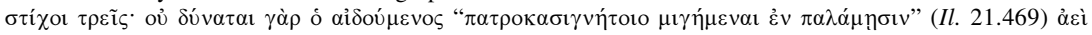

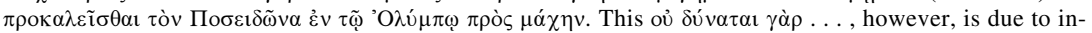
ternal inconsistency or $\alpha \dot{\alpha} \rho \dot{\varepsilon} \pi \varepsilon \imath \alpha$ of a character; according to Aristarchus it is "impossible" that Apollo once boasted that he was going to fight against his uncle Poseidon, if he is now afraid to face him. This is thus definitely not an athetesis due to something that is "impossible" from an objective point of view.

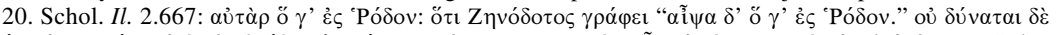

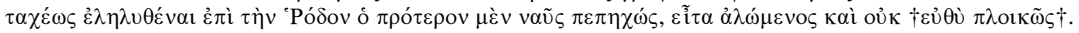

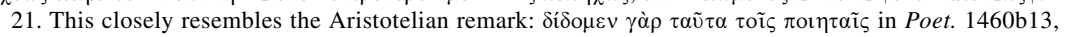
apropos of metaphors and glossai. 
A similar attitude is to be found in Aristotle when he comments on the episode of the bath in the Odyssey: Eurycleia's recognition of Odysseus is in itself $\alpha$ ' $\lambda \mathrm{o \gamma ov}$, but it is allowed because in this way the poet achieved $\tau$ ò

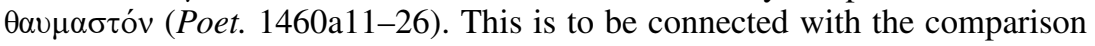
between tragedy and epic: according to Aristotle an advantage epic has over

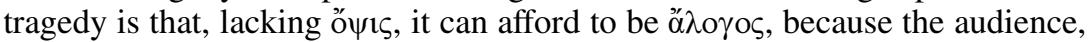
not seeing the plot performed, is likely to notice irrationalities and incongruities less (Poet. 1460a11-14):

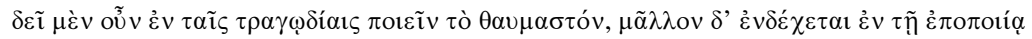

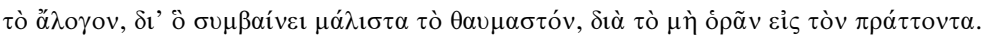

[The poet] should put what is amazing into his tragedies; but what is improbable, from which amazement arises most, is more admissible in epic because [the audience] does not see the person in action. (Trans. Janko 1987)

The main criterion for Aristarchus, as for Aristotle, is thus that of probability. Facts in the poems often receive comments along these lines: something takes place according to probability (Eikó $\tau \omega \varsigma$ ) and is therefore acceptable. For example, in the Doloneia (Il. 10.447) Diomedes addresses

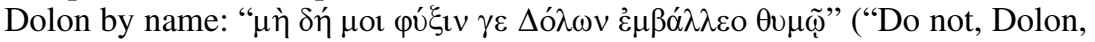
have in your mind any thought of escape"), and some ancient scholars found fault in the fact that Diomedes seems to know the name of Dolon, though this is the first time that they meet. On this basis they read $\delta o \lambda \tilde{\omega} v$, the participle of $\delta$ o $\lambda$ ó $\omega$, "to deceive" ("Do not have in your mind any thought of escape, trying to deceive me"). Aristarchus, however, defended the text: for him, it was probable (Eikós) that the Greeks knew the name of some of their enemies after ten years of siege (schol. Il. 10.447a):

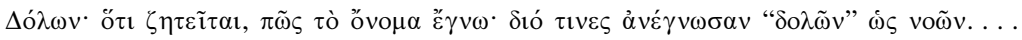

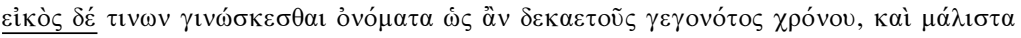

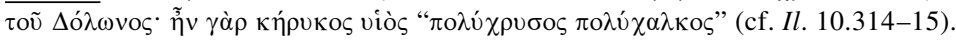

Dolon: [the diple is] because there is a question about how [Diomedes] knew his name;

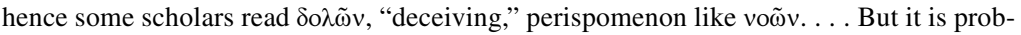
able that they knew the names of some of them, since a decade had passed [with them there], and in particular the name of Dolon. For he was son of a herald, "rich in gold, rich in bronze" (cf. Il. 10.314-15).

This criterion of probability is mainly expressed in Aristonicus' scholia by the couple $\pi \imath \theta \alpha v o$ s/ $\alpha \dot{\pi} \theta \alpha v o s$. It is one of the most common justifications given for an athetesis or for rejecting Zenodotus' readings which, according to Aristarchus, often lack believability. For example, in the assembly of the Achaean leaders at Iliad 2.50-86, Aristarchus did not find believable Zenodotus' reading according to which Agamemnon stands up to speak in front of only seven heroes (schol. Il. 2.55a: ö $\tau$ Z Z

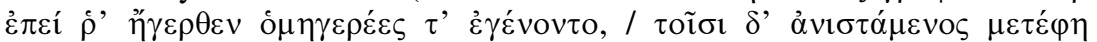

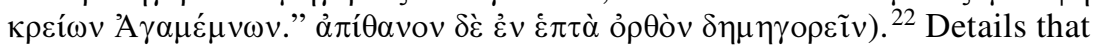


seem to go against human chronology are rejected on the same ground, as, for example, that Aethra, the maid of Helen, is to be identified with the mother of Theseus, who would have been extremely old by then (schol. Il. 3.144a):

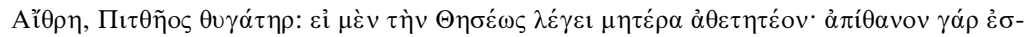

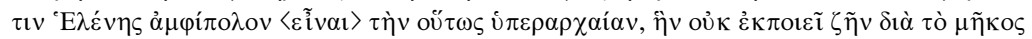

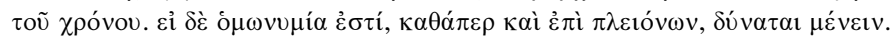

Aethra, the daughter of Pittheus: if Homer means the mother of Theseus, [the line] must be athetized. For it is unbelievable that such a very old woman be the maid of Helen. It is impossible that she has been living for such a long time. If instead it is a case of homonymy, as happens in many other cases, [the line] can remain. ${ }^{23}$

Also the famous problem of the dual in Iliad 9 is solved by Aristarchus with the criterion of credibility: there are only two people present, Odysseus and Ajax, because, if Phoenix were also present, it would not be believable to have Odysseus leading, since Phoenix was older (schol. Il. 9.192a):

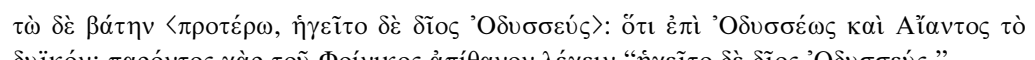

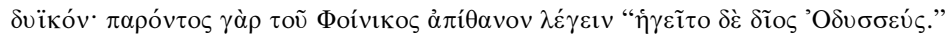

The two of them came forward, and noble Odysseus led the way: [the diple is] because the dual is for Odysseus and Ajax. For if Phoenix had been present, it would have been unbelievable to say "noble Odysseus led the way."

The criterion of believability plays a role even in the supernatural episodes

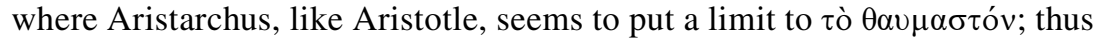
within the microcosm of the epos, although the supernatural is allowed, believability still applies. For example, in poetry it is fine for an animal to speak, like Xanthus, the horse of Achilles. However, it is too much to have him speak like a learned man or a seer foretelling his destiny to Achilles, as happens at Iliad 19.416-17, lines that Aristarchus rejected (schol. Il. 19.416-17a):

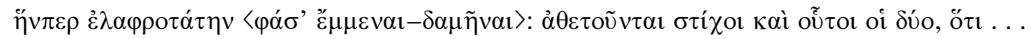

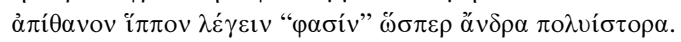

[we may be running together with the blows of Zephyrus] who they say is the lightest of all things; [yet still your destiny is] to be killed [in force by a god and a mortal].... these two lines also are athetized because . . . it is unbelievable for a horse to say "they say, etc.," like a knowledgeable man. ${ }^{24}$

Or, again, it is acceptable to have gods intervening in human affairs disguised as human beings. However, at Iliad 21.290, when Poseidon and Athena, disguised as two men, go to Achilles, it is not believable for Poseidon to say "Athena and I will help you," as Aristarchus remarked in schol. Il.

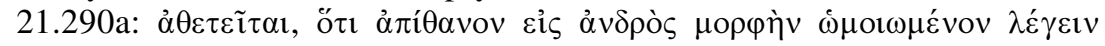

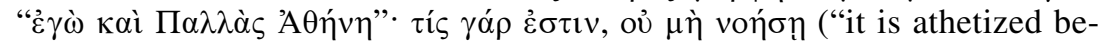
cause it is not believable that disguised as a mortal he says 'Athena and I.' For Achilles will not understand who he is"). How could Achilles know that these two men were divinities? 


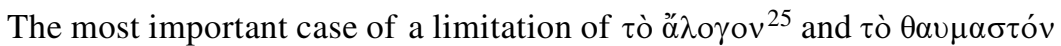
is the second part of the Nekyia (Od. 11.568 [565?]-627), where Odysseus claims to have seen Minos, Orion, Tityus, Tantalus, Sisyphus, and Heracles. Notwithstanding the admissibility of a "marvelous" journey to the Underworld, and although the lines are not bad in style, this episode was rejected as suspicious by Aristarchus. Odysseus never enters Hades but remains at the gate of Erebus (cf. Od. 11.37, 150, 563), and therefore could never have seen all these mythical examples of divine justice and wickedness being punished. ${ }^{26}$ The scholia by Aristonicus bear witness to a long series of comments by Aristarchus along these lines: how can Minos come to the sacrificial blood? Does he go with all the people he is going to judge together

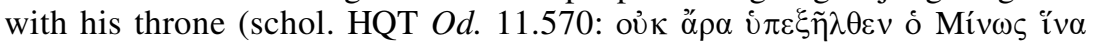

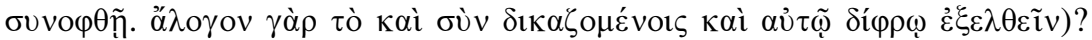
How can Orion hunt in Hades? How could he come forward with all the beasts

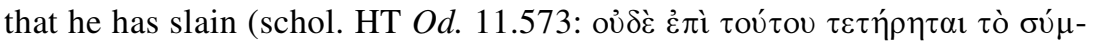

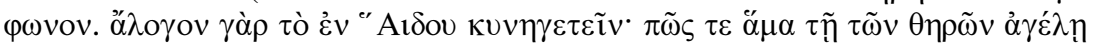

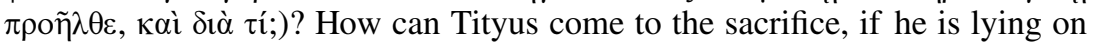
the ground with his liver devoured by two vultures (schol. QT Od. 11.577:

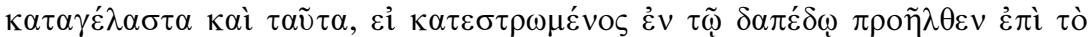

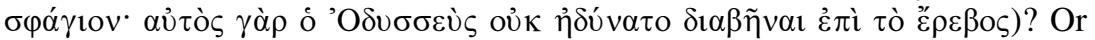
how can Tantalus come to the sacrifice, together with the trees and the marshy lake in which he lies? Or how did Odysseus see what was within from outside

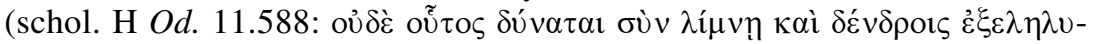

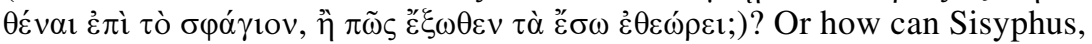
who must push the huge stone up a hill, come to the sacrifice (schol. QT Od.

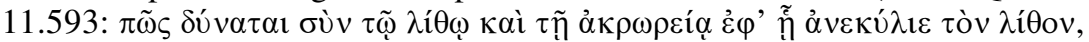

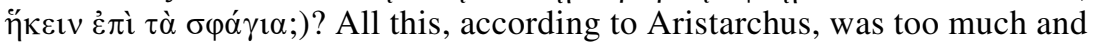
the risk was that, instead of being astonishing, the episode became ridiculous (on which see pp. 298-99 below).

\subsection{Aristarchus: Internal Contradictions}

The conception of the work of poetry as a microcosm with its own rules leads to the principle of noncontradiction. Avoiding inconsistencies within the plot is a cardinal principle for Aristotle, who argues repeatedly against what is $u \pi \varepsilon v \alpha v \tau$ íov (Poet. 1455a22-26): 27

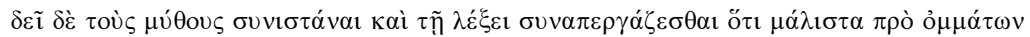

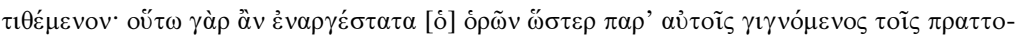

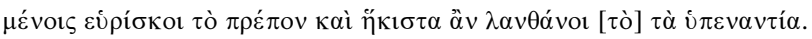

In constructing his plots and using diction to bring them to completion, [the poet] should put [the events] before his eyes as much as he can. In this way, seeing them very

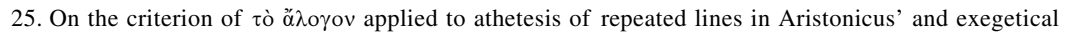
scholia, see Lührs 1992, 167-94.

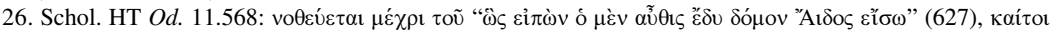

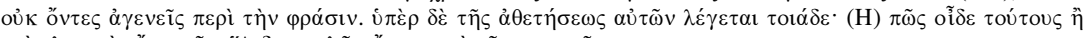

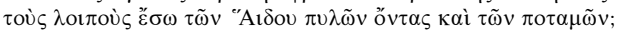

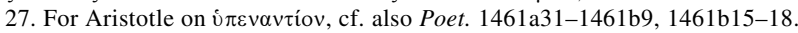


vividly as if he were actually present at the actions [he represents], he can discover what is suitable, and is least likely to miss contradictions. (Trans. Janko 1987)

Internal contradictions and inconsistencies are constantly rejected by Aristarchus too, who seems to have developed Aristotle's theory into a more complete system, where the philologist has to work on a text as a self-standing unity that must be purged of internal contradictions. Aristarchus takes ex-

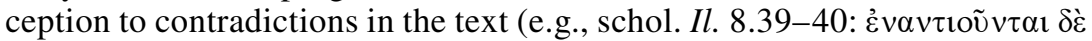

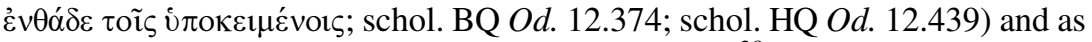
a rule, when this happens, he is in favor of athetesis. ${ }^{28} \mathrm{He}$ also argues against Zenodotus for readings that are contrary to some data present in the poems. ${ }^{29}$ The idea that something is consistent or inconsistent with the rest of the plot is expressed in Aristonicus' scholia with comments like $\sigma \nu \mu \varphi \omega ́ v \omega \varsigma$ ("in harmony," "in agreement with") or $\alpha \sigma v \mu \varphi \omega ́ v \omega \varsigma$ ("discordant," "in disagreement with"). 'A $\sigma \nu \mu \varphi \omega ́ v \omega \varsigma$ is used to argue against readings and interpretations by Zenodotus or other colleagues that Aristarchus does not share because they contradict some other passage within the poem (schol. Il. 4.339b, $8.19)$. On the contrary, a line is $\sigma \nu \mu \varphi \omega ́ v \omega \varsigma$ with the rest of the poem when Aristarchus wants to defend Homer against his detractors or against the $\delta 1 \alpha \sigma \kappa \varepsilon v \alpha \sigma \tau \alpha i$ (schol. Il. 3.230a), or defend his own readings (schol. Il. 7.330b, 8.562). Alternatively, the same idea is expressed with $\mu \alpha \chi^{\prime} \sigma \nu \tau \alpha \mathrm{l} /-\varepsilon \tau \alpha \mathrm{l}$ ("they/it contradict[s]"), that is, that one or more lines are at odds ( $\mu \alpha \dot{\chi} \varepsilon \tau \alpha \mathrm{l} /-\mathrm{ov} \tau \alpha \mathrm{l})$ with what has been said or known before, as in schol. H Od. 11.452: $\mu \alpha \chi$ ó $\mu \varepsilon v o r$

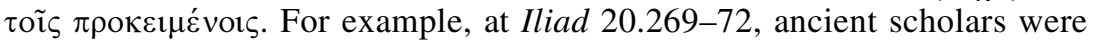
puzzled that Aeneas' spear reaches the golden plate of Achilles' shield, having pierced the two external plates, one of bronze and the other of tin, as if the shield had the golden layer underneath, hidden by those of bronze and tin. Aristarchus solved the problem by athetizing the lines, because according to him these lines not only were odd in terms of content (why was the gold hidden by tin and bronze?), but, moreover, they were in clear contradiction with what we know about the shield of Achilles as described at Iliad 18.478607, where its surface is clearly made of gold (schol. Il. 20.269-72a: $\dot{\alpha} \theta \varepsilon-$

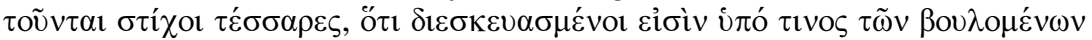

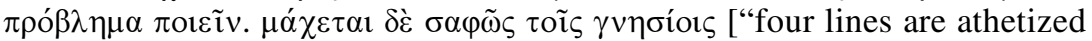
because they were added by someone of those who want to create a question. For these lines are clearly in contradiction with those that are genuine"]).

On the other hand, in Aristonicus' scholia oủ $\mu \alpha \chi^{\prime} \varepsilon \tau \alpha \mathrm{t}$ is used to solve a problem by showing that in Homer there are no internal contradictions. ${ }^{30}$ One famous question $(\zeta \eta ் \eta \mu \alpha)$ was that of how many times Hector and Achilles ran around Troy, because at Iliad 22.208 we read: $\alpha \lambda \lambda \lambda^{\prime}$ ó $\tau \varepsilon \delta \dot{\eta} \tau$ ò

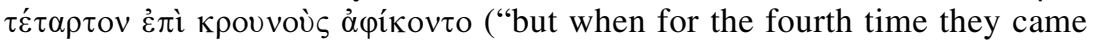

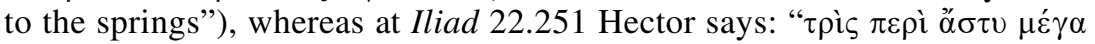

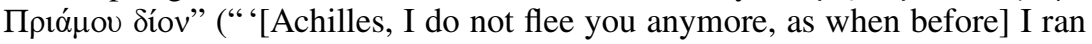
three times around the great city of Priam,"). Ancient scholars had taken 
exception to this passage, as Aristarchus noticed in schol. Il. $22.208 \mathrm{a}^{2}$ :

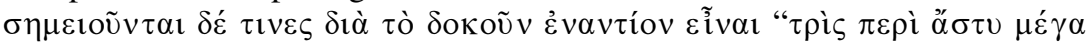

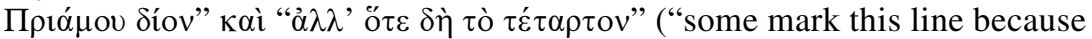
of the apparent contradiction between 'I ran three times around the great city of Priam' and 'but when for the fourth time'"). Aristarchus, however, clarified and solved the problem by arguing that there were three full laps, but in the fourth they went as far as the fountain but did not go right around the city. Therefore there was no contradiction between the two lines (schol.

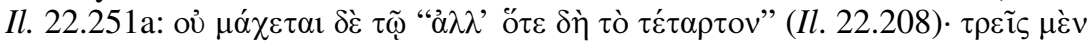

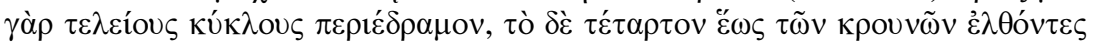

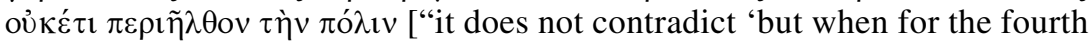
time' (Il. 22.208): for they ran in three full circles and in the fourth they arrived at the fountains and did not go around the city"]). ${ }^{31}$

\section{Aristotelian Theory and Aristarchean Practice: H@H}

At Poetics 1448a1-18, Aristotle states that every mimetic art represents

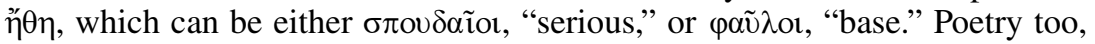
then, has to choose which $\ddot{\eta} \theta \eta$ are to be the target of mimesis, and hence it is divided according to the characters that it is going to imitate. In this regard, epic and tragedy are identical, in that both of them represent "admirable," "serious" people (Poet. 1449b9-10):

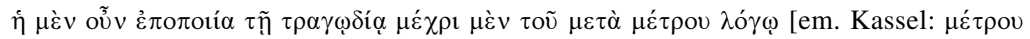

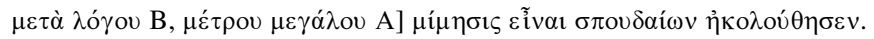

Epic poetry follows tragedy insofar as it is a representation of serious people which uses speech in verse. (Trans. Janko 1987)

Hence, what is valid for tragedy with regard to characters is to be considered valid for epos too. Characters of tragedy and epic must be $\sigma \pi$ ovo $\alpha$ ĩot, "serious," and better than they are in reality. Hence they must not be caricatures of real people, as happens in comedy, because everything that is ridiculous is to be avoided in tragedy and epic. When Aristotle comes to a detailed account of tragic/epic characters (Poet., chap. 15), he first states

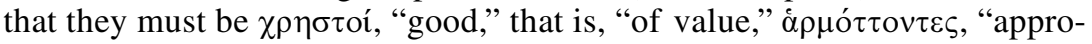

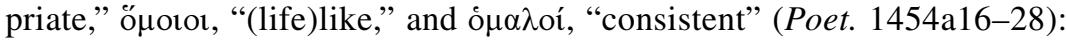

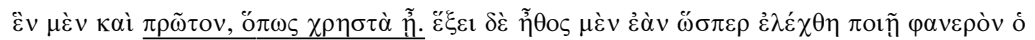

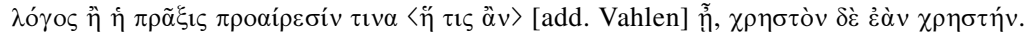

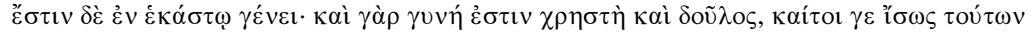

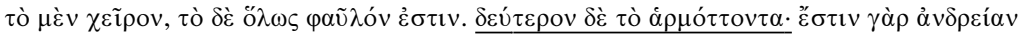

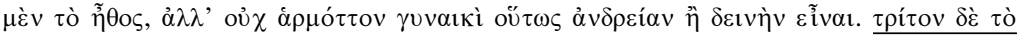

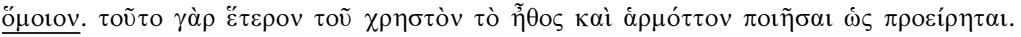

31. In analyzing plot, Aristotle deals also with the difference between simple and complex plots (Poet. 1452a12-18), which are characterized by the presence of $\alpha v \alpha \gamma v \omega \rho t \sigma \mu o ́ \varsigma$ and $\pi \varepsilon \rho \imath \pi \dot{\varepsilon} \tau \varepsilon 1 \alpha$. These concepts are not present in Aristarchus, which is probably due to the fact that they are more part of a theoretical discussion of a literary work than concepts that could be used in his philological activity. For the same reason, Aristarchus does not seem to have taken much from Aristotle's sections on the different parts of tragedy (Poet. 1452b14-27), and on the different kinds of actions (pitiful, fearful, recognitions, Poet. 1453b1-1454a15). This essential difference between the work of Aristotle (theory) and that of Aristarchus (practice) is fundamental. 


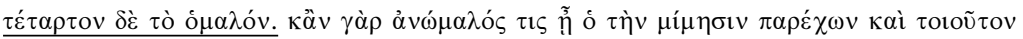

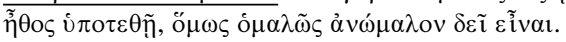

First and foremost, the characters should be good. [The tragedy] will have character if, as we said, the speech or the action makes obvious a decision of whatever sort; it will have a good character, if it makes obvious a good decision. [Good character] can exist in every class [of person]; for a woman can be good, and a slave can, although the first of these [classes] may be inferior and the second wholly worthless. Second, [they should be] appropriate. It is possible to be manly in character, but it is not appropriate for a woman to be so manly or clever. Third, [the character should be life-]like. This is different from making the character good and appropriate in the way already stated. Fourth, [the character should be] consistent. If the model for the representation is somebody inconsistent, and such a character is intended, even so it should be consistently inconsistent. (Trans. Janko 1987)

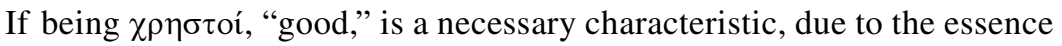
of tragedy, which represents "serious" ( $\sigma \pi \mathrm{ov \delta \alpha \tilde {i } o t ) ~ a c t i o n s ~ a n d ~ c h a r a c t e r s , ~}$

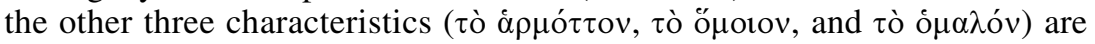

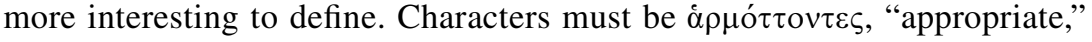
in the sense that each character must fit the characteristics of the kind of individual it represents. This concept is later on coupled with that of $\pi \rho \varepsilon$ ź (Poet.

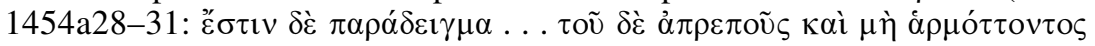

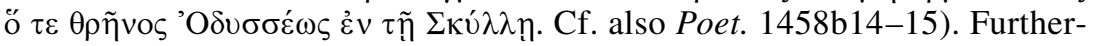
more, characters must be ó $\mu o 1$, "(life)like," "similar" to their real model (in "real life" or in the mythical tradition to which the poet refers). ${ }^{32}$ Finally, they must be o $\mu \alpha \lambda$ oí, "consistent," and not behaving in a contradictory way. The last three characteristics are thus sharply distinct. Tò $\alpha \rho \mu$ ó $\tau$ ov refers to the relationship between the "type" the poet has in mind and how the character relates to it, so how "convincing" the representation of that particular human being is (considered in terms of gender, age, social status, etc.). Tò ó otov instead refers to the relationship between reality outside the work of poetry (i.e., the real life or the mythical tradition in the background) and the characters, in the sense that the audience has to recognize the character as someone similar to and comparable to people from their own experience, whereas the idea of $\tau$ ò ó $\mu \alpha \lambda$ óv is an internal criterion to judge the development of the character within the poetical work. Aristotle then summarizes

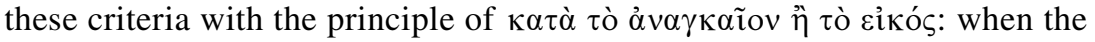
poet portrays a character, as when putting the plot together, he has to aim at necessity and probability (Poet.1454a33-36):

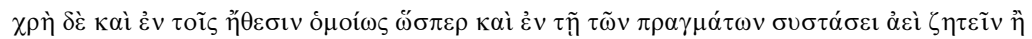

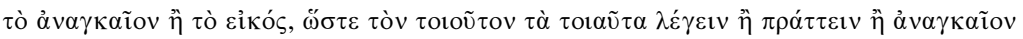

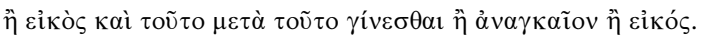

In the characters too, exactly as in the structure of the incidents, [the poet] ought always to seek what is either necessary or probable, so that it is either necessary or probable that a person of such-and-such a sort say or do things of the same sort, and it is either necessary or probable that this [incident] happen after that one. (Trans. Janko 1987)

32. Cf. Janko 1987, 109: “the character should be 'like,' literally; but like what? This means either that the type should be recognisable to us as one we know, i.e. lifelike, or that it should be like us. As there is no explanation or example, Aristotle must have regarded the meaning as obvious. . . Clearly a character who is not lifelike will also be unlike ourselves, so the first explanation brings the second with it." 
The analysis of characters plays a central role in the second book of the Rhetoric (Rh. 2.12-17.1388b31-1391b6), because the knowledge of different characters is essential for a good orator. Here Aristotle develops these ideas especially in the direction of what is typical of different ages. In three beautiful chapters (Rh. 2.12-14), where he is explaining how a good orator should depict various $\ddot{\eta} \theta \eta$ in order to be persuasive, Aristotle highlights the main characteristics of young people (rash, optimistic, generous), old people (prone to reflect, pessimistic, selfish) and mature people (a middle way between the two). If one wants to achieve a good mimesis, one cannot depict a character with the characteristic of another age, because this would go against the criterion of $\tau$ ò $\alpha \rho \mu o ́ \tau \tau o v$. In this light the poet must be particularly careful when putting words into the mouths of his characters, because their $\lambda \dot{\varepsilon} \xi_{1} \varsigma$ must be $\eta \dot{\theta} \kappa \eta \dot{n}$, consistent with the character that uses it, as Aristotle makes clear in the third book of the Rhetoric (1408a10-11):

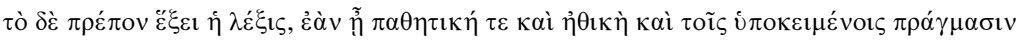 $\dot{\alpha} v \alpha \dot{\lambda} \mathrm{o \gamma ov}$.
}

Your language will be appropriate if it expresses emotion and character, and it corresponds to its subject. (Trans. Roberts 1984)

This is because each age and class has its own mode of expression, and a good representation of a character must consider these characteristics (Rh. 1408a26-32):

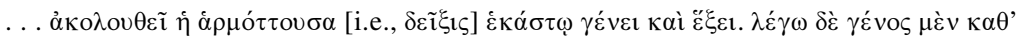

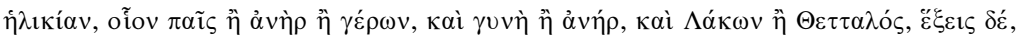

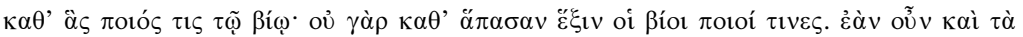

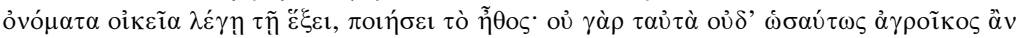

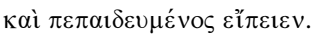

\begin{abstract}
Each class of men, each type of disposition, will have its own appropriate way of letting the truth appear. Under "class" I include differences of age, as boy, man, or old man; of sex, as man or woman; of nationality, as Spartan or Thessalian. By "dispositions" I here mean those dispositions only which determine the character of a man's life, for it is not every disposition that does this. If, then, a speaker uses the very words which are in keeping with a particular disposition, he will reproduce the corresponding character; for a rustic and an educated man will not say the same things nor speak in the same way. (Trans. Roberts 1984)
\end{abstract}

The interest in characterization in Homer is very well attested for Aristarchus too. In Iliad 1.117, when Agamemnon, angered by the response of Calchas, agrees to give Chryseis back and says, "I prefer that the army be

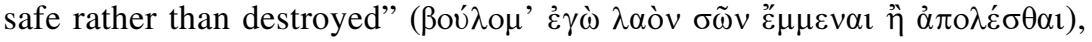
Aristarchus rejected the athetesis of Zenodotus (according to whom the line

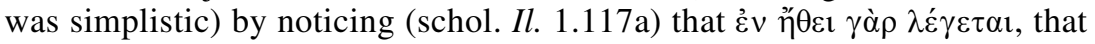
is, the line suits the character of Agamemnon (whom Aristarchus, probably, did not hold in great esteem). ${ }^{33}$

33. Cf. also schol. Il. 15.505a, where Aristarchus notes that the line is according to Ajax' character

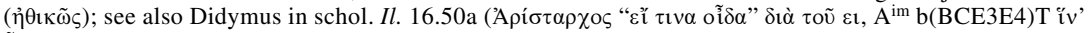

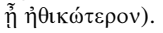


Aristarchus seems to have followed Aristotle in arguing for consistency and credibility of characters. Characters, according to Aristarchus, should

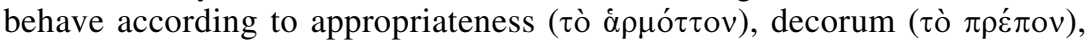

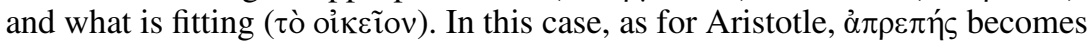
a synonym of oủ $\chi \dot{\alpha} \rho \mu$ ó $\tau \omega v$, in the sense of "not convenient," "unsuitable" to the human type at issue. ${ }^{34}$ This criterion actually embraces all the subtle distinctions of the Poetics as well as those of the Rhetoric: characters are

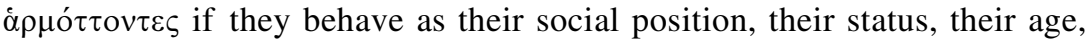
their present situation, or their "mythical model" require. Aristarchus thus denies "unheroic" words to Homeric heroes. It was unacceptable to have Agamemnon dwelling on the pleasure he was going to enjoy from Chryseis

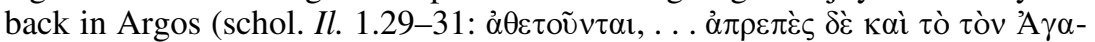

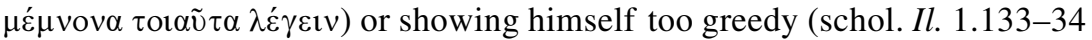

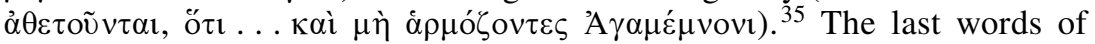
Achilles to Patroclus as he is about to go to battle, in which Achilles wishes that every Trojan and every Greek may die so that only the two of them could survive and sack Troy, ${ }^{36}$ were athetized by Aristarchus, because in his view they were not in line with Achilles' character (schol. Il. 16.97-100a):

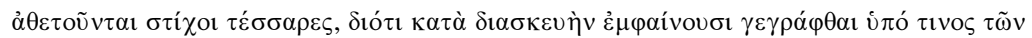

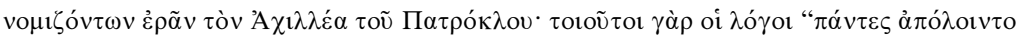

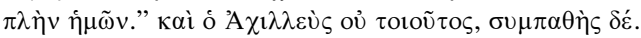

Four lines are athetized because in their construction they appear to have been written by one of those who believed that Achilles was in love with Patroclus. For such are the words "[I wish] that all might die but the two of us" [i.e., these words support the idea of an Achilles in love with Patroclus]. But Achilles is not like that, but is instead sympathetic [to the Greeks].

Aristarchus also refuses to accept an Achilles who pettily insults Aeneas

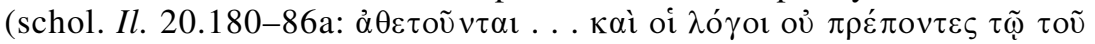
A $\chi \imath \lambda \lambda \dot{\varepsilon} \omega \varsigma \pi \rho \circ \sigma \omega \pi \omega)$. Base insults to Diomedes are denied to Hector too

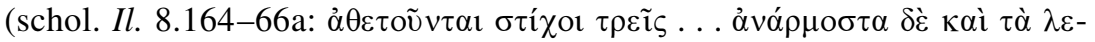
$\gamma o ́ \mu \varepsilon v \alpha \tau o \tilde{i} \varsigma \pi \rho \circ \sigma \omega ́ \pi$ or $\varsigma)$, a great hero who moreover, on another occasion, does not "hope," but rather "boasts," that is, "vaunts" that he will win (schol.

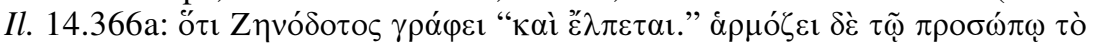

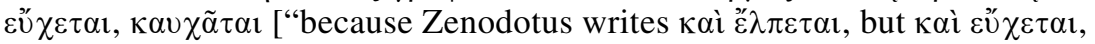
'he vaunts,' is fitting to the character']). Aristarchus also clearly deplores

34. This does not mean that, with the word $\alpha \operatorname{\pi } \rho \varepsilon \pi \eta \dot{\varsigma}$, Aristarchus implied a moral judgment of poetry;

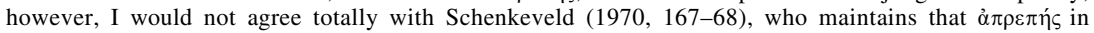
Aristarchean scholia is used only to point out a contradiction in the text. When it refers to characters, $\dot{\alpha} \pi \rho \varepsilon \pi \eta ́ s$ implies "contradiction" only in the sense of being contradictory to what a real individual in the

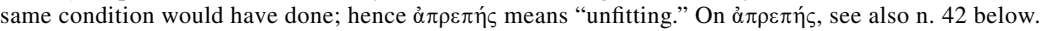

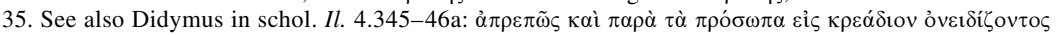

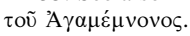

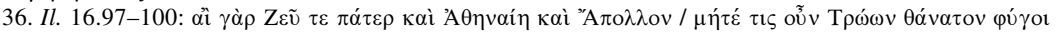

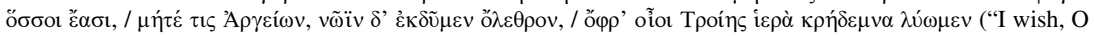
Zeus father and Athena and Apollo, that none of the Trojans, as many as they are, could escape death, nor any of the Argives, but that only the two of us could avoid destruction, so that we alone could loose the sacred veils of Troy"). 
Ajax' characterization as a miles gloriosus who brags of his military su-

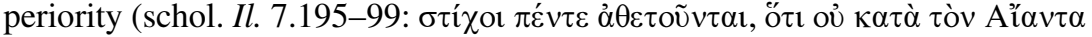

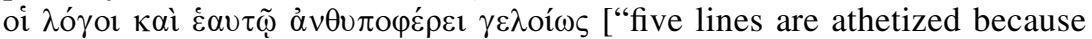
this speech is not worthy of Ajax and it is ridiculous that he replies to himself']). ${ }^{37}$ By the same token there are words that may suitably be said to kings and words that may suitably be said to subjects, like those that Odysseus speaks to the soldiers to keep them from going back home (Il. 2.203-6: "not all of us Achaeans are to be kings; the rule of many is not a good thing; let there be only one ruler, one king to whom the son of Cronos, crooked of counsel, has given the scepter and the laws in order that he can take counsel for them"). ${ }^{38}$ According to Aristarchus these lines should not be employed by Odysseus when Odysseus is addressing the rank and file (Il. 2.200-206), but should instead be transferred to a previous point, when he is addressing the other leaders (Il. 2.190-97). His point of view is clear from Aristonicus'

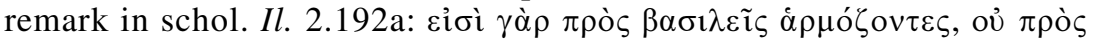
$\delta \eta \mu$ ó $\alpha \varsigma$ ("for these lines are suitable to kings, not to rank soldiers").

The same holds for women, who must behave properly, not give orders to superior beings like gods, as in the case of Helen rebuking Aphrodite at

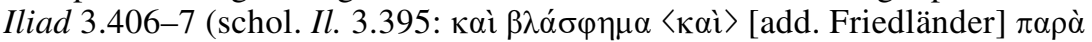

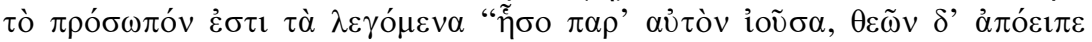

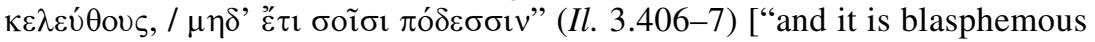
even for the character [i.e., Helen] to say: 'Go and sit by his side, and give up the way of the gods, and [do not go back to Olympus] with your feet' ']; or, as in the case of Andromache, giving tactical advice to her husband,

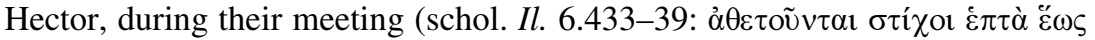

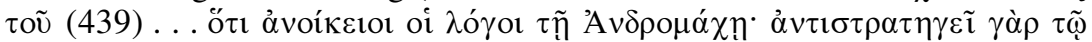

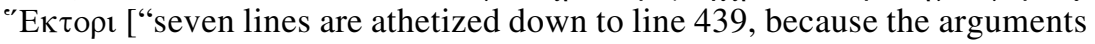
are not fitting for Andromache, since she is giving strategic advice instead of Hector"]. A young princess like Nausicaa was not allowed to dwell too much on the gossip people might have made upon seeing her enter the city

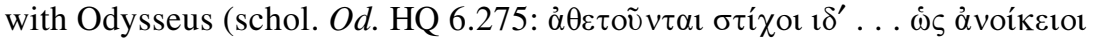

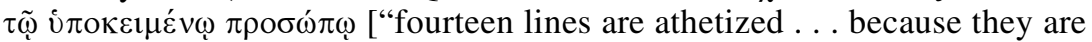
not fitting to the character in question"]. A mother like Thetis cannot give

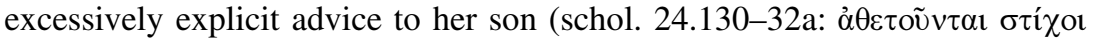

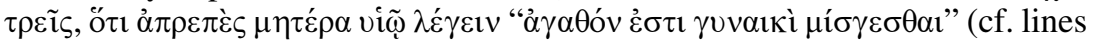
130-31) ["three lines are athetized because it is inappropriate for a mother to say to her son: 'it is good to have intercourse with a woman'"]).

As between men and women, there is a clear distinction between what is

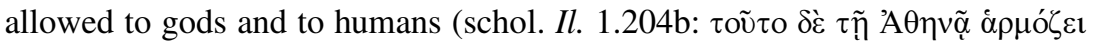
$\mu \tilde{\alpha} \lambda \lambda$ ov $\delta \iota_{\alpha} \beta \varepsilon \beta \alpha \iota \tilde{v} v$ ["but this sense of certainty about the future is more

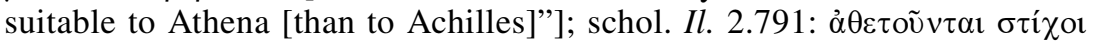

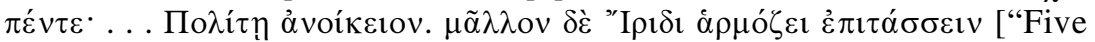

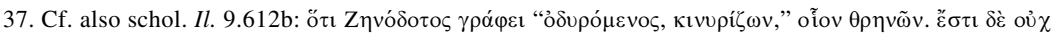

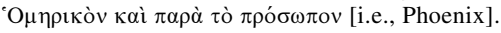

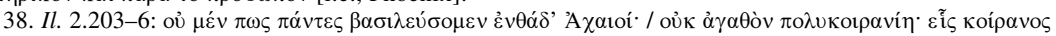

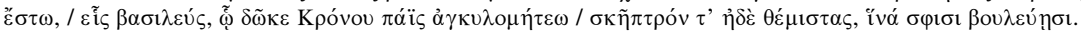


lines are athetized. . . . [it is] not appropriate for Polites. To give commands is more fitting to Iris"]). Also, the verbs suitable to the immortal gods are

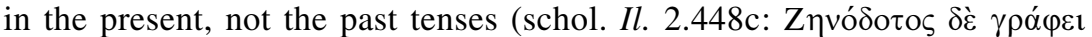

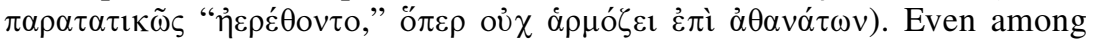
gods there is a hierarchy: what is permitted to Zeus is not allowed to Iris

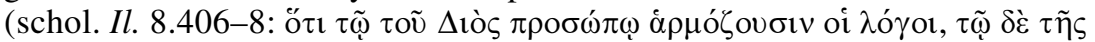

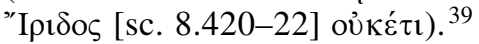

The distinction between Greeks and barbarians and what was fitting for a Greek hero to say played an interesting role in the athetesis of Iliad 16.237. Here Achilles prays to Zeus and says: "you did me honor, and

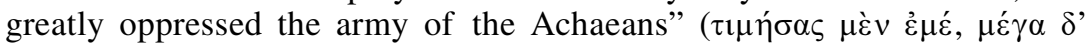
¿ै $\alpha$ o $\lambda \alpha$ òv A $\mathrm{A} \chi \alpha \iota \tilde{\omega} v)$. According to Aristarchus, the line was wrongly repeated from Iliad 1.454, where it was at the right place, when Chryses is praying to Apollo. For it was not likely for Achilles to rejoice at the defeat of the Greeks, whereas this was fitting for a barbarian enemy of the Greeks,

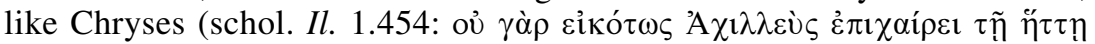

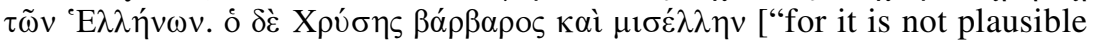
for Achilles to rejoice at the defeat of the Achaeans, but Chryses is a barbarian and enemy of the Greeks"]). ${ }^{40}$ The words of Aeneas to Achilles suggesting that they should not insult each other like women in the streets were athetized by Aristarchus for the same reasons, because they were more suitable to barbarians than to civilized Greeks (schol. Il. 20.251-55a $\mathrm{a}^{1}: \dot{\alpha} \theta \varepsilon-$

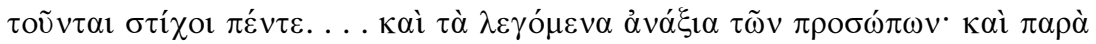

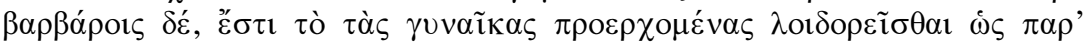

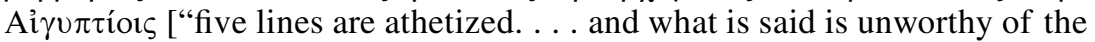
characters. Among barbarians it is possible to have women come out and hurl abuse, as among the Egyptians"]). ${ }^{41}$

An important point is that words and actions must be suitable to the age and the social level of the characters. A typical case is Iliad 3.156-60, when the old Trojans see Helen arriving on the tower and remark that it is shameful to fight for a woman, no matter how beautiful she is. The scene is

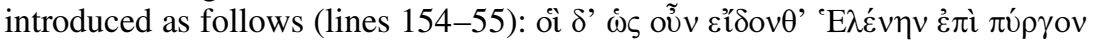

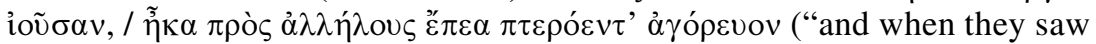
Helen arriving upon the tower, they softly spoke winged words to one another"). Aristarchus argued against a variant suggested by Zenodotus, $\tilde{\omega} \kappa \alpha$, "swiftly," instead of ᄁ๊ $\kappa \alpha$, "softly," "in a low tone," because that adverb was $\alpha \pi \rho \varepsilon \pi \varepsilon \zeta$ if it referred to Helen (a noble woman cannot come "quickly,"

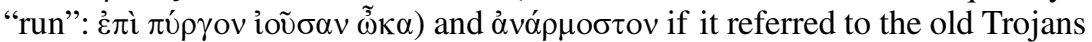

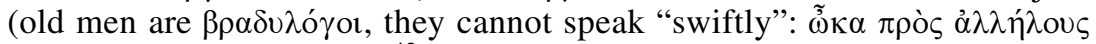
ع́ $\pi \varepsilon \alpha \pi \tau \varepsilon \rho o ́ \varepsilon v \tau$ ’ $\alpha \gamma o ́ \rho \varepsilon v o v) .{ }^{42}$ Similar to this case is that of Odyssey 15.45 ,

39. Cf. schol. Il. 8.420-24a.

40. Cf. also schol. Il. 16.237 a.

41. Cf. Lührs 1992, 117-20, esp. 119.

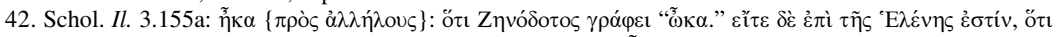

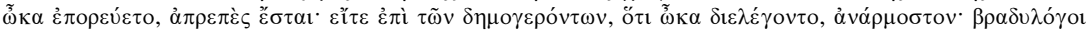

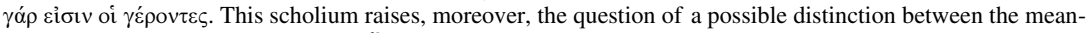

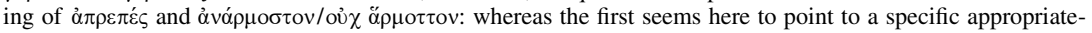
ness, related to the character Helen (running is not fitting to Helen), the latter seems to hint at a generic 
where Telemachus wakes up Pisistratus by touching him with his foot $(\lambda \grave{\alpha} \xi$

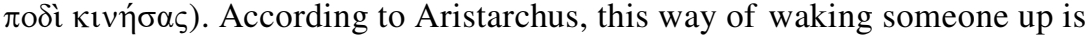
more suitable to Nestor, who is old and does it at Iliad 10.158 to wake up Diomedes. ${ }^{43}$ These comments seem to have behind them the same ideas about old age as we read in the Rhetoric, Book 2.13, though, admittedly, Aristotle does not talk about the "slowness" and lack of strength of old people, but focuses on a psychological description. The same idea of old age as measured and never inclined to excess suggests that measured and dignified language is fitting to old kings like Priam ${ }^{44}$ and Alcinous. ${ }^{45}$ The reverse is true for young people, who should respect the old and restrain themselves from speaking too openly. ${ }^{46}$ Also unfitting are references to marriage and family for

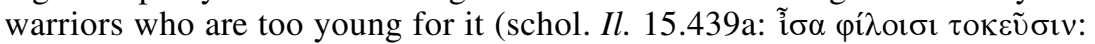

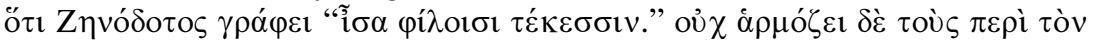

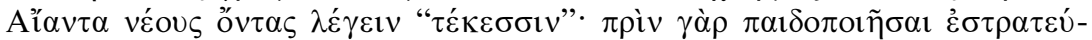

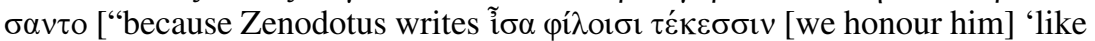

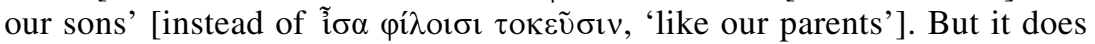
not fit those around Ajax, who are young, to say 'like our sons.' They served in the army before begetting children"]).

A case where the contacts between Aristotelian theory and Aristarchus' practice are particularly strong and interesting is Odyssey 4.156-60. Here, Pisistratus speaks to Menelaus and confirms that Telemachus is Odysseus' son:

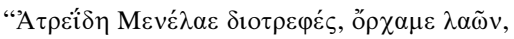

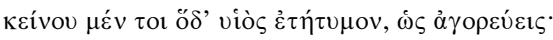

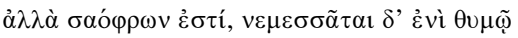

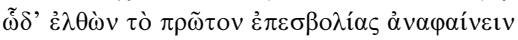

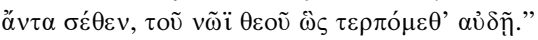

Divine Menelaus, son of Atreus, leader of people, he is indeed that man's son, as you say. But he is prudent and feels shame in his heart that on his first coming he might show himself hasty in speaking in the presence of you, in whose voice we both take delight as in a god's.

appropriateness, related to the characteristics of the human type depicted (speaking quickly is not fitting to old people in general). However, the evidence from the other scholia, which use the two terms inconsistently, prevents the acceptance of such conclusions.

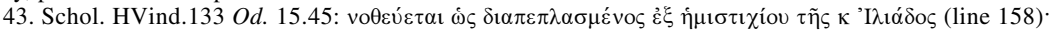

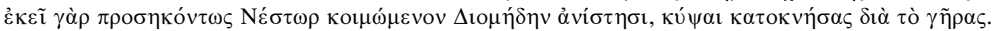

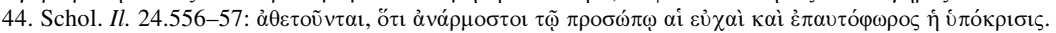

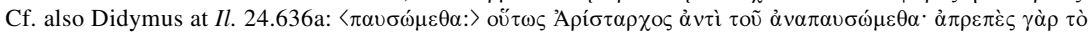
$\lambda \varepsilon ́ \gamma \varepsilon ı v$

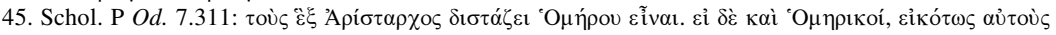

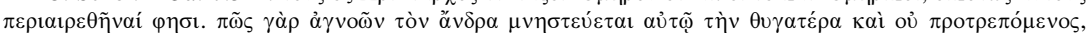
$\dot{\alpha} \lambda \lambda \dot{\alpha} \lambda ı \pi \alpha \rho \tilde{\omega} v$; Cf. also schol. Il. 9.56-57, about Nestor saying to Diomedes: "You might even be my son":

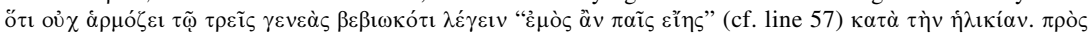

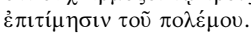

46. In this sense, one could quote the case of $O d$. 2.316-17, lines probably athetized by Aristarchus on the grounds that Telemachus here is threatening the suitors too strongly (schol. EM Od. 2.325: ᄁ๊ $\mu \alpha \dot{\lambda} \lambda \alpha] \beta \varepsilon \beta \alpha 1 \omega-$

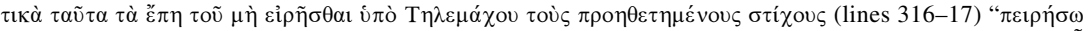
ळ̆ $\varsigma$ '

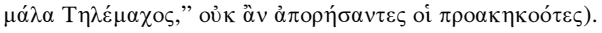


Lines 158-60 were athetized by Aristarchus because they were considered contrary to the traditional usage ( $\tau \dot{\alpha} \pi \alpha ́ \tau p \iota \alpha$ ) and not appropriate for the character of Pisistratus; moreover, they were superfluous and utterly unsuitable

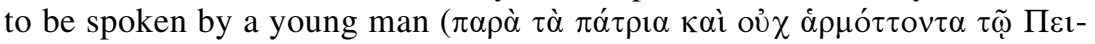

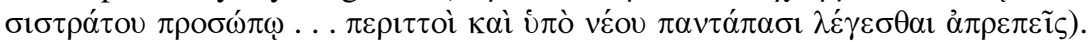
This comment by Aristarchus finds a striking overlap with what Aristotle had stated in the Rhetoric (1395a2-6 and 1404b15-16):

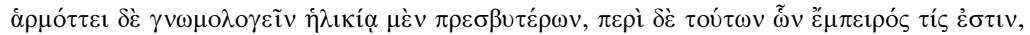

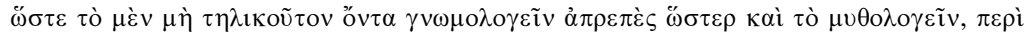

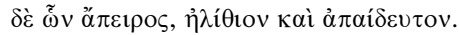

The use of maxims is appropriate only to elderly men, and in handling subjects in which the speaker is experienced. For a young man to use them is-like telling storiesunbecoming; to use them in handling things in which one has no experience is silly and ill-bred. (Trans. Roberts 1984)

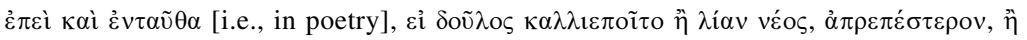
$\pi \varepsilon \rho i ̀ ~ \lambda i ́ \alpha v ~ \mu \iota \kappa \rho \tilde{v} v$.

For even in poetry, it is not quite appropriate that fine language should be used by a slave or a very young man, or about very trivial subjects. (Trans. Roberts 1984)

A young man cannot speak in $\gamma \nu \tilde{\omega} \mu \alpha \iota$ either for Aristotle or for Aristarchus. ${ }^{47}$

\section{Aristotelian Theory and Aristarchean Practice: $\Delta$ ianoiA}

Aristotle defines $\delta$ tóvot $\alpha$ as the thought-element, everything transmitted and expressed with words (Poet. 1450a6-7 and 1456a36-1456b2):

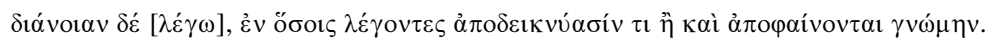

By "reasoning," I mean the way in which they use speech to demonstrate something or indeed to make some general statement. (Trans. Janko 1987)

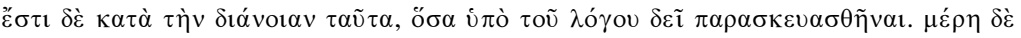

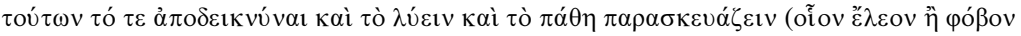

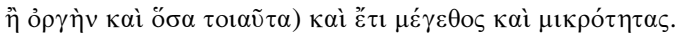

All [the effects] that have to be produced by speech fall under reasoning. The types of these are demonstration and refutation, the production of emotions (e.g., pity, terror, anger, etc.), and again [arguments about things'] importance or unimportance. (Trans. Janko 1987)

Thus, with $\delta$ ióvor $\alpha$ we are dealing with the content of speeches, either uttered by characters or by the poet himself when he intervenes in the narrative. In this sense it is opposed to $\lambda \dot{\varepsilon}^{\prime} \xi 1 \zeta$, which is the form in which the thought takes shape. In particular, Aristotle states that the two main parts of

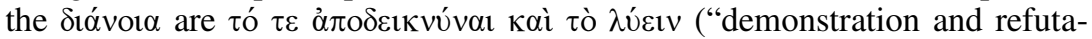

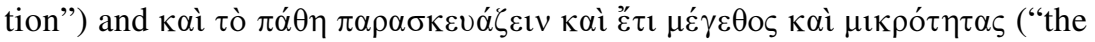

47. The attention toward characterization and what is fitting for each character is also used in the so-called $\lambda \cup ́ \sigma \varepsilon ı \zeta ~ \varepsilon ̉ \kappa ~ \tau о \tilde{~} \pi \rho \circ \sigma \omega ́ \pi \circ v$, which are typical of Aristarchus' exegesis; on this principle, see Dachs 1913. 
production of emotions, and again importance or unimportance"). Aristotle

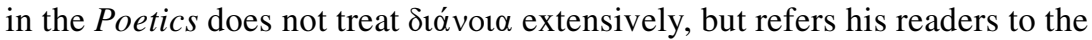
Rhetoric, where the opposition between the thought-element versus the formal element in speeches is well stated (Rh. 1404a18-19):

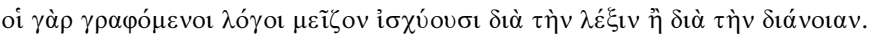

Speeches of the written kind owe more of their effect to their language than to their thought. (Trans. Roberts 1984) $)^{48}$

The thought expressed by the characters or by the poet must thus reflect the general "ethos" of a poetic work. In particular, the $\delta$ ióvot $\alpha$ of tragedy and epic must be in keeping with the "solemnity" ( $\sigma \varepsilon \mu \nu$ ó $\tau \varsigma)$ and seriousness that characterize both genres. Therefore, anything that is $\gamma \varepsilon \lambda$ oĩov, "ridiculous," must be avoided, because this is typical of comedy and low genres and extraneous to tragedy and epic (Poet. 1449a32-37):

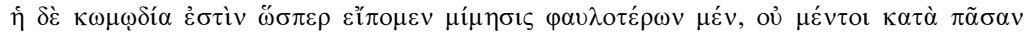

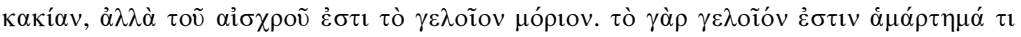

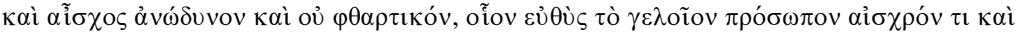

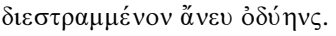

Comedy is, as we have said, a representation of people who are rather inferior-not, however, with respect to every [kind of] vice, but the laughable is [only] a part of what is ugly. For the laughable is a sort of error or ugliness that is not painful and destructive, just as, evidently, a laughable mask is something ugly and distorted without pain. (Trans. Janko 1987) ${ }^{49}$

Aristarchus certainly shared the idea that epic is mainly concerned with "serious" content, for he often rejects lines expressing a ridiculous thought. In particular, there are some interesting cases where Aristarchus argues against Homer himself. At Iliad 12.176, describing the battle at the Achaean wall, the poet says: "it would be too much toil for me, as if I were a god,

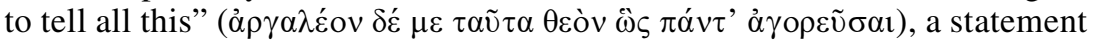

48. A correspondence with this dichotomy between form $(\lambda \dot{\varepsilon} \xi \mathrm{l} \zeta)$ and thought ( $\delta \operatorname{tó}^{\mathrm{v} o t \alpha)}$ can be found in the three books of the Rhetoric, where the first two deal with the thought, whereas Book 3 deals with the style. In particular, Book 1, where Aristotle analyzes the different kind of speeches and arguments, seems

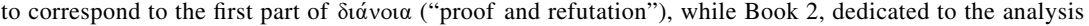
of the different emotions and characters that the good orator must imitate in order to persuade, reflects the second and third parts ("the arousing of feelings and then again exaggeration and depreciation"). Book 3 , instead, is about the $\pi \varepsilon \zeta \grave{\eta} \lambda \dot{\varepsilon}^{\prime} \xi 1 \zeta$, the prose style, extraneous to poetry. This is probably why in the Poetics

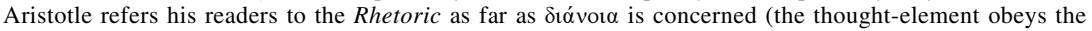
same rules both for prose and for poetry); whereas he needs to have a proper section on style in the Poetics

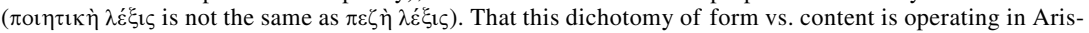

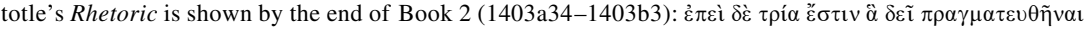

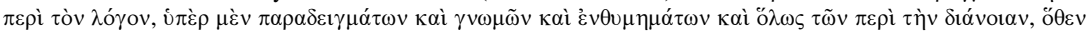

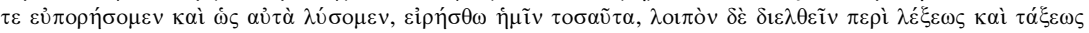
("Three points must be studied in making a speech and now we have completed the account of examples, maxims, enthymemes, and in general the thought-element- the way to invent and refute arguments. We have next to discuss language and arrangement," trans. Roberts 1984).

49. On the opposition between $\gamma \varepsilon \lambda$ oiov (typical of comedy) and $\sigma \varepsilon \mu \nu v^{\prime}$ (typical of tragedy), cf. Rh. 1406b6-

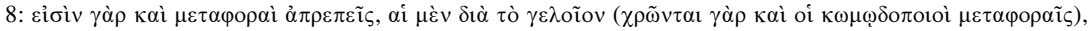

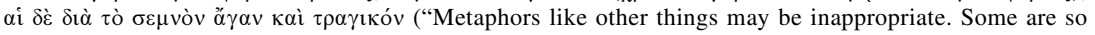
because they are ridiculous (they are indeed used by comic poets too). Others are too grand and tragic," trans. Roberts 1984, modified). 
that Aristarchus rejected as $\gamma \varepsilon \lambda$ oĩov. ${ }^{50}$ For the same reason he found fault in the concluding line of the long catalogue of the Nereids mourning Patroclus (Il. 18.38-49). Here, after giving a list of thirty-three Nereids, the poet concludes: "and all the other Nereids that were in the depth of the sea" (" $\alpha \lambda \lambda \alpha$ l

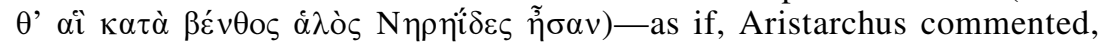
Homer first intended to list them all by name, but then got tired (schol.

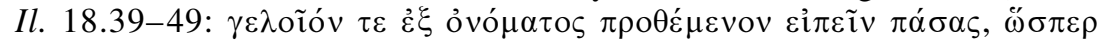

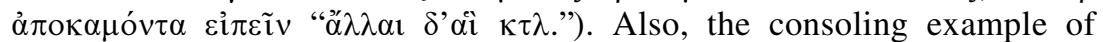
Niobe that Achilles tells to Priam is considered ridiculous, because a straightforward paraphrase of the exemplum would give: "eat, because Niobe too

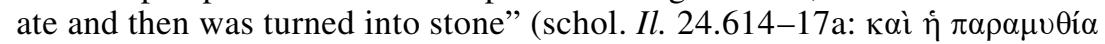

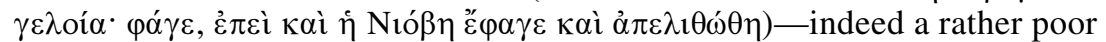
encouragement. $^{51}$

Aristarchus found fault also with the words uttered by the characters. For example, at Iliad 8.189 Hector talking to his horses and inviting them to

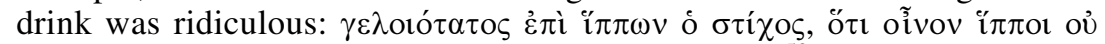

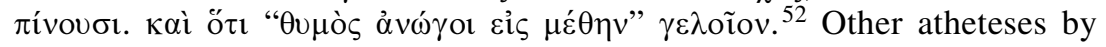
Aristarchus due to a $\gamma \varepsilon \lambda$ oĩov thought in the words of characters are attested at Iliad 10.409-11 (Odysseus to Dolon); ${ }^{53}$ Iliad 14.376-77 (Poseidon to the Greeks); Odyssey 4.158-60 (Pisistratus to Menelaus); Odyssey 4.553 (Menelaus to Proteus); Odyssey 11.157-59 (Anticlea to Odysseus); Odyssey 14.495 (Odysseus to the Greeks at Troy). Alternatively, Aristarchus notes something $\gamma \varepsilon \lambda$ oiov in the readings of predecessors (Zenodotus in particular), which are therefore to be rejected, at Iliad 3.74 (Paris to Hector) and Iliad 23.94 (Achilles to Patroclus' ghost). ${ }^{54}$

The simile comparing Achilles and Hector running around Troy to a dream in which the pursuer cannot reach the one who runs away at Iliad 22.199-

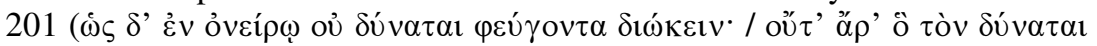

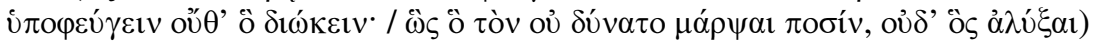
was athetized by Aristarchus, as he found the lines "cheap" both in style

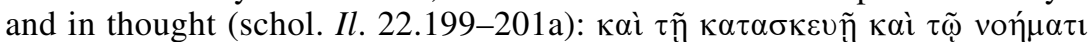

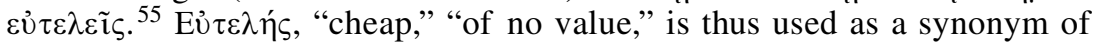
$\gamma \varepsilon \lambda$ oĩos in the scholia of Aristonicus to convey the idea that the content or the style of a passage are not consonant with the serious content of the epos. Aristotle likewise employs the adjective $\varepsilon \cup ̉ \tau \varepsilon \lambda \eta \dot{\zeta}$ when comparing two

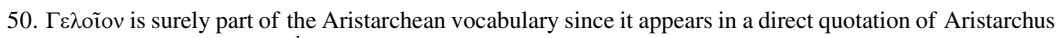
by Didymus in schol. Il. $2.420 \mathrm{a}^{1}$.

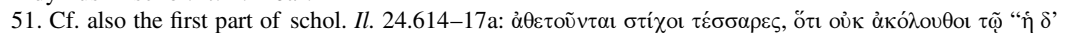

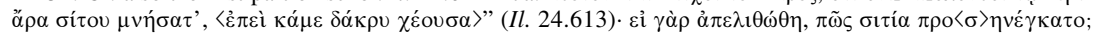

52. Cf. Lührs 1992, 46 n. 92.

53. On this athetesis, see Lührs 1992, 226-28.

54. A rather close synonym of $\gamma \varepsilon \lambda \circ \tilde{i} o v$ is $\varepsilon \dot{\eta} \eta \eta \eta \varsigma$, "foolish." Aristarchus athetized lines because of their "foolishness" in the thought expressed by the character: at Il. 1.139 (Agamemnon to Achilles); Il. 2.80-81 (in schol. Il. 2.76a, Nestor commenting on Agamemnon's dream); Il. 8.185 ( $\dot{\eta} \pi \rho \circ \sigma \varphi \omega ́ v \sigma \iota \varsigma$, i.e., the address

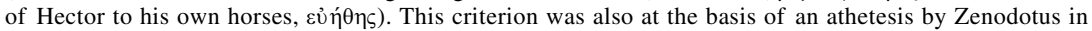

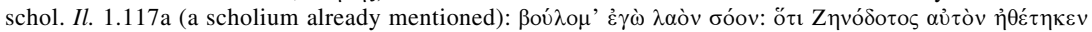

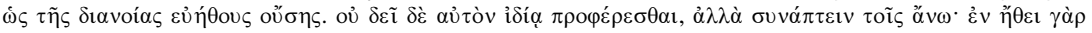
$\lambda \dot{\varepsilon} \gamma \varepsilon \tau \alpha$.

55. Though for different reasons, the $\delta \boldsymbol{i}^{\omega} \xi_{1 \zeta}$ of Hector by Achilles in Il. 22 was problematic for Aristotle too (cf. Poet. 1460a11-18). 
contrasting types of authors: the $\sigma \varepsilon \mu$ voí who will write tragedies and the

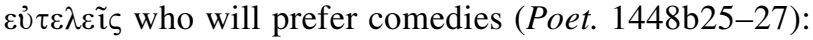

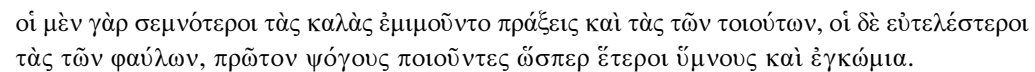

The grander people represented fine actions, i.e., those of fine persons, the more ordinary people represented those of inferior ones, at first composing invectives, just as the others composed hymns and praise-poems. (Trans. Janko 1987)

Therefore, in Homer we must avoid everything that is $\varepsilon \dot{\tau} \tau \varepsilon \lambda \varepsilon \dot{\varepsilon} \varsigma$. And indeed, we find many Aristarchean atheteses on the basis that some lines are $\varepsilon \dot{v} \tau \varepsilon \lambda \varepsilon \tilde{i} \zeta$

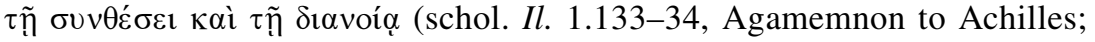
schol. Il. 15.212a, Poseidon to Iris; schol. Il. 16.93a, Achilles to Patroclus; schol. HP Od. 5.94-95, probably referring to lines 97-98, Hermes to

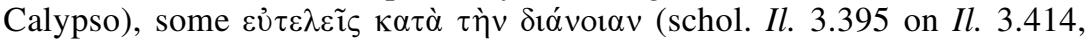

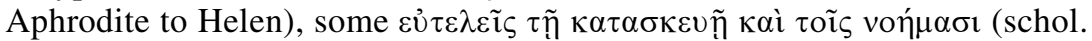
Il. 20.180-86a, Achilles to Aeneas). ${ }^{56}$

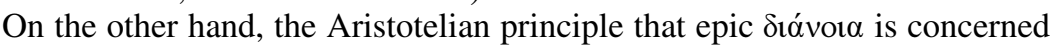
with or must express importance ( $\mu \varepsilon^{\gamma} \gamma \varepsilon \theta o \varsigma$; cf. Poet. 1456a36-1456b2 quoted above) seems to be at the basis of Aristarchean practice too. Arguing against an athetesis of Zenodotus in Iliad 17.260, Aristarchus maintained that those lines containing a comment by the poet himself $\left(\tau \tilde{\omega} v \delta{ }^{\prime}{ }^{\prime} \lambda \lambda \omega \nu \tau i \xi \kappa \varepsilon v \tilde{\eta} \sigma \mathrm{r}\right.$

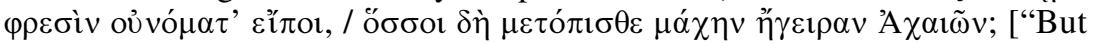
of the rest, what man of his own wit could name the names of all that came after these and aroused the battle of the Achaeans?"] were actually increasing the importance ( $\tau$ ò $\mu \varepsilon ́ \gamma \varepsilon \theta o \zeta$ ) of the battle for Patroclus' corpse (schol. Il.

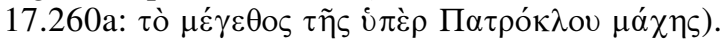

\section{Aristotelian Theory and Aristarchean Practice: $\Lambda$ E $\Xi$ I $\Sigma$}

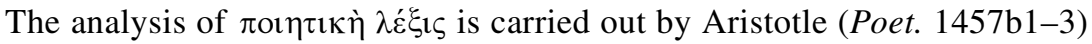

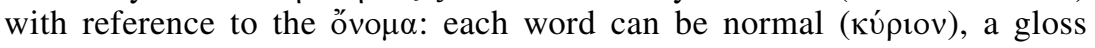

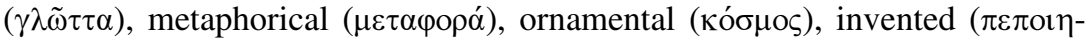

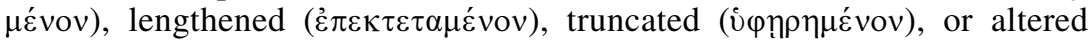
$(\dot{\varepsilon} \xi \eta \lambda \lambda \alpha \gamma \mu \dot{\varepsilon} v o v)$. Moreover, whereas the кúpiov usage is typical of the prose style, the other schemata are characteristic of poetic style. In particular, at Poetics 1459a9-10, glossai are said to be the most apt to epic; this, as already mentioned, is one of the points of contact between Aristotle and the work done at Alexandria, where collections of glossai were widely produced. However, poetic style cannot be reduced only to figures of speech; to be a good poet one has also to be clear (Poet. 1458a18-34):

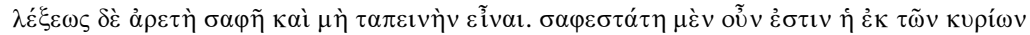

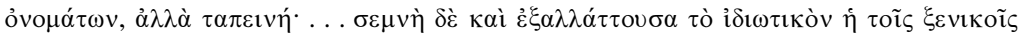

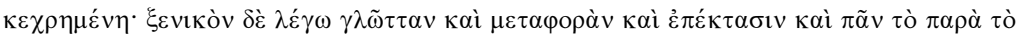

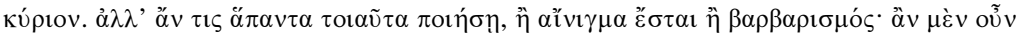

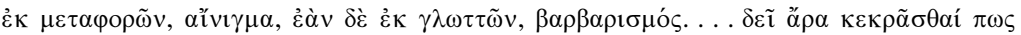

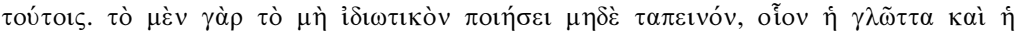

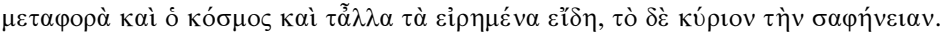

56. On this athetesis, see Lührs 1992, 191 n. 153. 
The virtue of diction is to be clear and not commonplace. Diction made up of standard names is the clearest, but it is commonplace. ... Diction that uses unfamiliar names is grand and altered from the everyday. By "unfamiliar," I mean the exotic [name], metaphor, lengthening and everything that is contrary to what is standard. But if someone makes all [the names] of this sort, [his poem] will be either a riddle or gibberish. If [it is composed] of metaphors, it will be a riddle; if of exotic [names], gibberish. . . [The poet], then, should mix these [two kinds] in some way. The first (i.e. the exotic name, metaphor, ornament and the other kinds we mentioned) will produce that which is not everyday and commonplace, and the standard name will produce clarity. (Trans. Janko 1987)

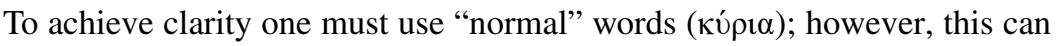
lead to $\tau \alpha \pi \varepsilon$ เvó $\tau \zeta$, , "meanness of style," which must be avoided in poetic style. Therefore poets also use words that get away from common language

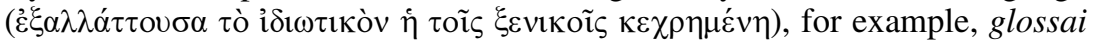
and metaphors. However, they must not be excessive, otherwise the result will be an $\alpha$ ívi $\gamma \mu \alpha$ (if there are too many metaphors) or a $\beta \alpha \rho \beta \alpha \rho \imath \sigma \mu$ ó (if there are too many glossai). ${ }^{57}$ The aim is thus to achieve an equilibrium between norm and novelty, where the true poet is able to mix the two and thus be at the same time both clear and striking.

Attention to both form and style is evident in Aristarchus; in particular, the definition of what is Homeric style and what is not seems to be the coherent development of the Aristotelian distinction between poetic and prosaic $\lambda \varepsilon^{\prime} \xi_{1 \zeta} .{ }^{58}$ As for Aristotle, for Aristarchus too language must first be

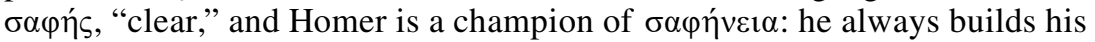

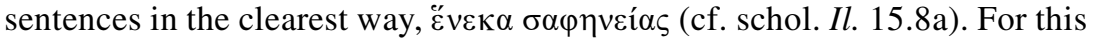

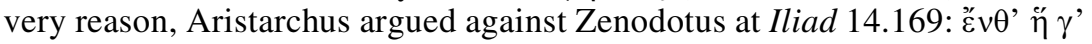

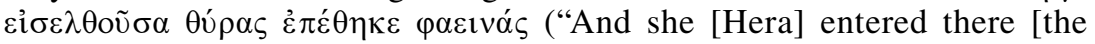
chamber], closed the bright doors"), where Zenodotus changed the finite verb $\dot{\varepsilon} \pi \dot{\varepsilon} \theta \eta \kappa \varepsilon$ into a participle $\dot{\varepsilon} \pi \imath \theta \varepsilon \tilde{\imath} \sigma \alpha$ (so that the main verb was to be found in line 171, кá $\theta \eta \rho \varepsilon v)$. Homer-Aristarchus argued-prefers to have another main clause with a finite verb at line 169 and thus to be clear and avoid a postponed principal clause. ${ }^{59}$

Aristotle in particular maintained that $\sigma \alpha \varphi \eta ́ v \varepsilon ı$ was due to the usage of кúpı $\alpha$ ỏvó $\alpha \alpha \tau$, "standard names." It is interesting how many times Aristarchus

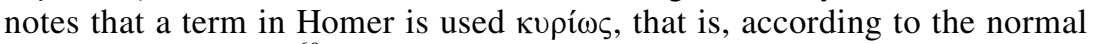
usage, hence "clear." 60 On the other hand, Aristarchus seems to be well aware of the characteristic of poetic language, which is allowed to depart from

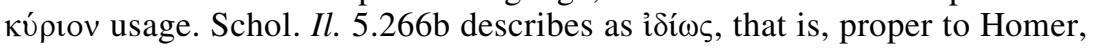
the usage of the word $\pi$ orvทं in this passage (in the sense of "price paid,"

57. For a similar analysis of prose style, see $R h .1404 \mathrm{~b} 1-1408 \mathrm{~b} 20$.

58. In this case, an important change in terminology happened, since for Aristarchus $\lambda \dot{\varepsilon} \xi_{1 \zeta}$ meant "word" and not "diction," "utterance," "style," as in Aristotle; cf. Matthaios 1999, 198-200; 1996, 68-69. To mean

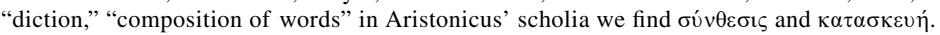

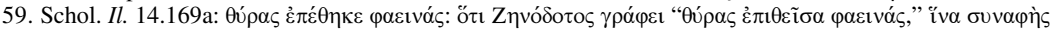

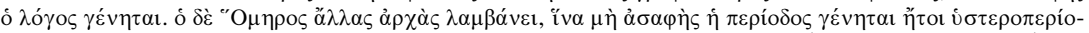

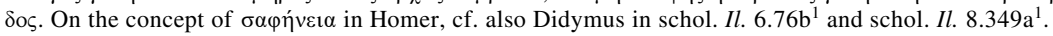

60. Cf. schol. Il. 4.141a, 7.146b, 7.255a, 10.75b, 11.523, 22.31, 22.319a, 22.489b. Aristarchus could not adopt the very word of Aristotle, кúptov óvo $\mu \alpha$, which, by that time, meant something different, denoting the grammatical category of "proper names" (or just "names"), as opposed to that of epithets; see Matthaios 1996, esp. 69-70; 1999, 218-25. 
"recompense") and opposes it to the standard usage (кטрí $\omega \varsigma$ ) of the word, as at Iliad 9.636 (in the sense of a "fine paid by the slayer to the kinsmen of

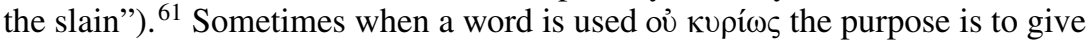
a deeper meaning, as at Iliad 2.670 where the image of Zeus pouring gold

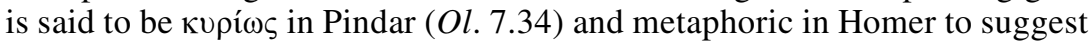

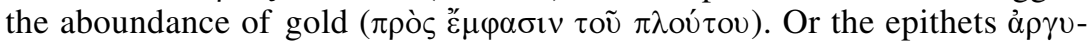

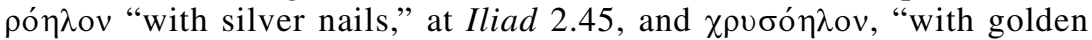
nails," at Iliad 11.29-30-both referring to the sword of Agamemnon-are

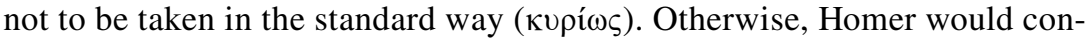
tradict himself and depict Agamemnon's sword once as silver nailed, once as golden nailed. Rather, they are used ornamentally as a poetical device. ${ }^{62}$ Aristarchus is also keen to note metaphorical usages in Homer, as in schol.

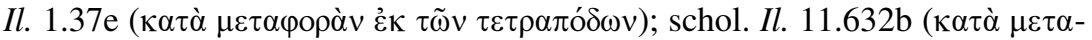


Just as Aristotle allows poetic diction to depart from common language in order to avoid $\tau \alpha \pi \varepsilon \imath$ vó $\rceil \varsigma$, , "meanness," so Aristarchus athetizes lines

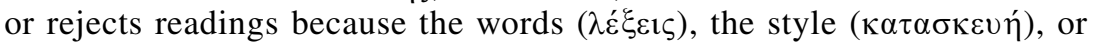
the composition $(\sigma u ́ v \theta \varepsilon \sigma ı)^{64}$ are $\varepsilon \cup ̉ \tau \varepsilon \lambda \varepsilon \tilde{\mathbf{i}} \varsigma$, as happens in schol. Il. 2.314b

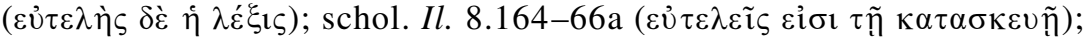

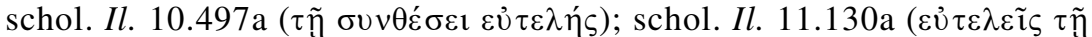

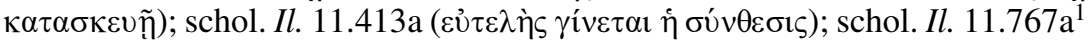

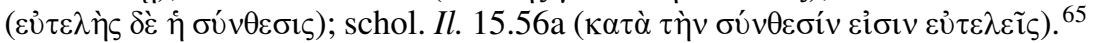
However, notwithstanding this shift from common language, Homer never $\beta \alpha \rho \beta \alpha \rho i ́ \zeta \varepsilon 1 . ~ H e n c e$, anything against grammatical correctness must be rejected,

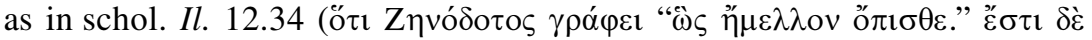

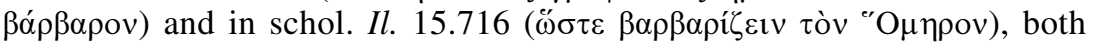
against Zenodotus' readings.

Finally, some interesting parallels with the Rhetoric. For prose, one of the most serious vices is to be $\psi v \chi \rho \rho^{\prime} v$, "frigid," and this can arise from four causes: the usage of glossai, of excessive epithets, of strange compounds, and of improper metaphors, all devices that pertain to poetry rather than prose (Rh. 1405b35-1406a13):

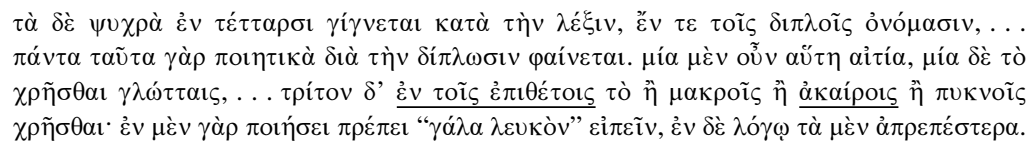

Frigidities in language may take any of four forms: the misuse of compound words, . . . The way all these words are compounded makes them, we feel, fit for verse only. This, then, is one form in which bad taste is shown. Another is the employment of strange

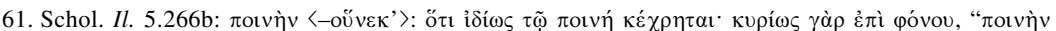
$\delta \varepsilon \xi \alpha \mu \varepsilon \dot{v} v "(I l .9 .636) . .$. Similarly, the distinction between a usage $\kappa v \rho i \omega \varsigma$ and a usage that is not standard is noted by Aristarchus in schol. Il. 8.439a and schol. Il. 10.528b.

62. Cf. schol. Il. 2.45a.

63. Cf. also schol. Il. 1.51c, 2.49b, 4.521a, 5.21b, 5.299a, 11.390a, 13.147a, 13.317, 13.420, 13.745-46a,

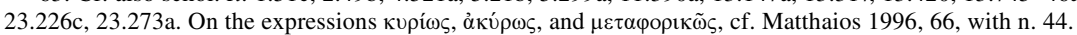

64. In particular, on $\sigma u ́ v \theta \varepsilon \sigma ı \varsigma$ as a technical term, see Schironi, in Bottai and Schironi 1997, 1058-62.

65. On the athetesis of $I l$. 15.56, see Lührs 1992, 129-32. The word $\varepsilon v ̉ \tau \varepsilon \eta \dot{\zeta}$ is used by Aristotle (Poet. 1458b19-22) as a negative term to compare two different results in composing iambi: a good one by Aeschylus and a bad one by Euripides. 
words. ... A third form is the use of long, unseasonable, or frequent epithets. It is appropriate enough for a poet to talk of "white milk," but in prose such epithets are sometimes lacking in appropriateness. (Trans. Roberts 1984)

In Aristarchus, we find the same principle applied to poetry, which must avoid too many prose elements: some atheteses are due to the style, which

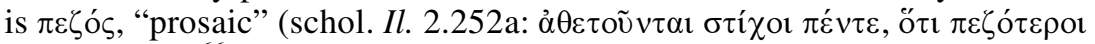
$\tau \tilde{\eta} \sigma 0 v \theta \varepsilon \dot{\varepsilon} \sigma \varepsilon 1){ }^{66}$

On the other hand, Aristarchus, like Aristotle, takes exception to epithets

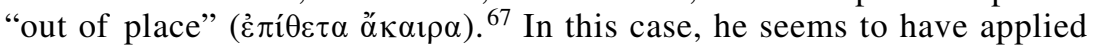
Aristotle's principles to poetic style, because sometimes he rejects a line because the epithet there is őkatpos. This happens at Iliad 21.331, when

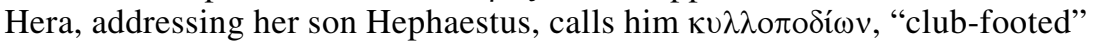

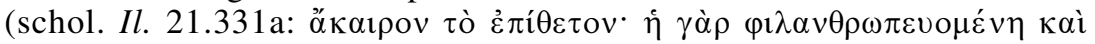

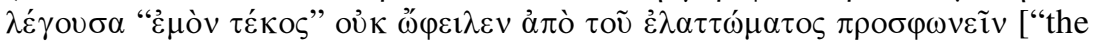
epithet is out of place. For since she regularly shows kindness and says 'my child,' she ought not to have addressed him by mentioning his defect"]), or at Iliad 21.218, when the Scamander, talking to Achilles, calls his streams

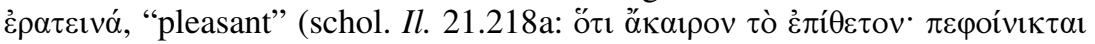

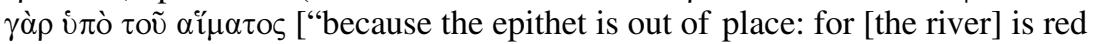
with blood"]). Iliad 23.581 was athetized because Menelaus, angry with Anti-

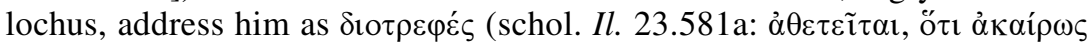

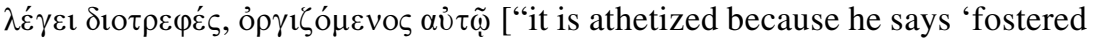
of Zeus' inappositely, since he is angry with him"]). Often Aristarchus finds

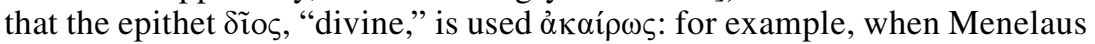

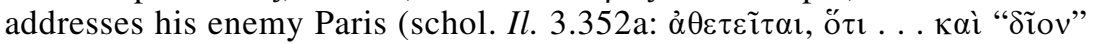

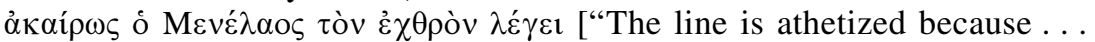
and Menelaus calls his enemy 'divine' inappositely"]), or for the voluptuous Anteia (schol. Il. 6.160a), or for Hector when he is talking to himself (schol.

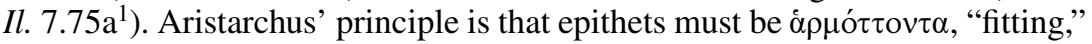
to the names and contexts to which they refer, just as Aristotle explains $(R h$. 1405a10-13):

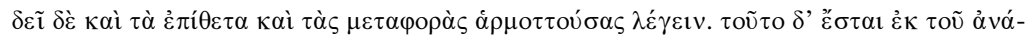

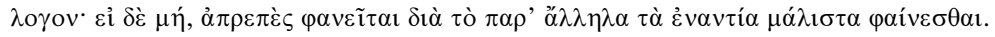

Metaphors, like epithets, must be fitting, which means that they must fairly correspond to the thing signified: failing this, their inappropriateness will be conspicuous: the want of harmony between two things is emphasized by their being placed side by side. (Trans. Roberts 1984)

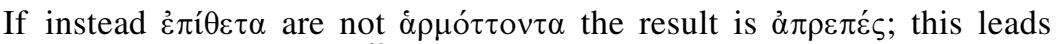
Aristarchus to an athetesis. ${ }^{68}$

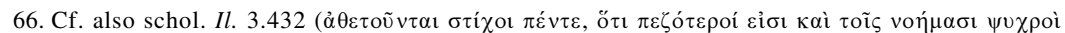

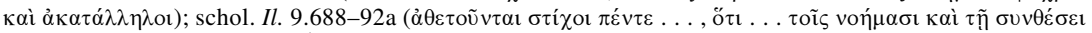

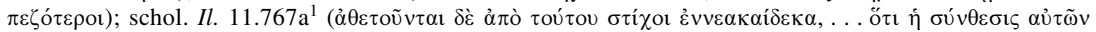
$\pi \varepsilon \zeta)^{\prime}$.

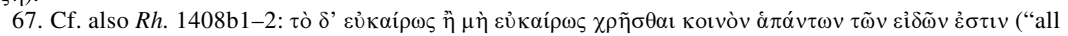
the variations of oratorial style are capable of being used in season or out of season," trans. Roberts 1984). 68. Cf. Matthaios 1999, 237-38. 


\section{Aristotle, Aristarchus, and the HELLENISTIC LITERARY CRITICISM}

The parallels between Aristotle's theoretical statements in the Poetics and in the Rhetoric and Aristarchus' practice in his " $\varepsilon \kappa \delta$ ' $\kappa \iota \varsigma$ of Homer must not be taken, however, as evidence of a "direct" dependence of Aristarchus on Aristotle. Aristarchus is not a Peripatetic, or, better, is only a Peripatetic to the extent that the other scholars and scientists working at the Museum or in Alexandria were Peripatetic. Aristotle seems to have shaped their rigorous and systematic approach to knowledge, also providing them with a set of methodological tools to proceed in their studies, such as the principle of cause and effect, analogical reasoning, the combination of teleological and mechanistic views of natural phenomena, and the analysis of concrete data in order to offer a systematic view of the kosmos. ${ }^{69}$ This is what, mutatis mutandis, we find in Aristarchus, who, among the "philologists" of his own time, such as Crates of Mallos and the so-called крıєıкоí, is certainly the most concrete, systematic, and anti-speculative. This is an important point, because all of these similarities between Aristotle, Aristarchus and, in general, the Alexandrian philological school $^{70}$ in the field of literary criticism are not particularly meaningful if it cannot be demonstrated at the same time that this is a unique case and that the majority of the other contemporary grammarians, philologists, and critics were adopting other views. It is thus necessary to focus on Aristarchus' colleagues.

One of the most important sources for Hellenistic poetic theories is $O n$ Poems by Philodemus of Gadara. In Books 1 and 2, Philodemus, using Crates' work surveying the literary views of the "critics" and of the "philosophers,"

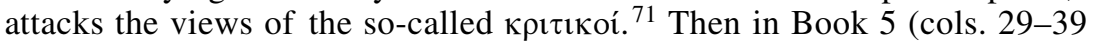
Mangoni), based on the previous work of his teacher Zeno of Sidon, he surveys thirteen different views of poetry. ${ }^{72}$ Unfortunately, these two accounts are not completely consistent with each other and, moreover, it is not always easy to judge who held particular views. However, some general points and a certain degree of detail for some of these critics and literary theorists can be reached. A brief review of them will show how Aristarchus' approach to poetry is different from (and more Aristotelian than) all these other theories.

\subsection{The крıєıкоí (Heracleodorus, Pausimachus, and the Others) and Crates}

The term крıєıкó $\varsigma$, as Janko has pointed out, is in itself very ambiguous because by the time of Philodemus it meant generically "literary critic." 73 How-

69. The same relationship with Aristotle can be envisaged for Erasistratus; cf. von Staden 1997.

70. I am focusing on Aristarchus because among the Alexandrians he is the one about whom we know most and also he is considered the acme of Alexandrian philological activity. However, Zenodotus, Eratosthenes, and Aristophanes of Byzantium share, at least in part, the same Aristotelian approach with Aristarchus. On Zenodotus, see Nickau 1977, 132-83; on Eratosthenes, see p. 309 below. The contrast thus is between the Alexandrian school (with Aristarchus as the main and final representative of it) and the other schools flourishing in other parts of the Hellenistic world, like Pergamum and Athens.

71. The best survey of these views is that by Janko $(2000,120-89)$.

72. For an analysis of these columns, see Asmis 1992b.

73. Cf. Janko 2000, 126. 
ever, we tend to use this name to label a group of scholars that considered sounds and composition the primary (if not sole) criterion for judging poetry, ${ }^{74}$ as Philodemus explains in PHerc. 1676, col. 6, 2-9 (from On Poems, Book 2):

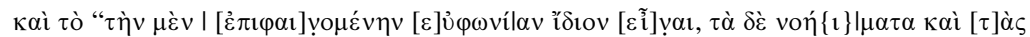

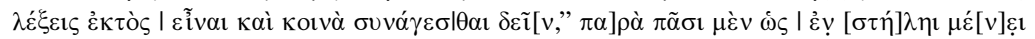

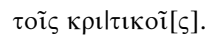

that "the supervenient euphony is particular [to poetry], but the contents and the words are external [to it] and must be considered common [to all]" is fixed as if in stone among all the critics. (Trans. Janko 2000, 124-25) ${ }^{75}$
\end{abstract}

According to these critics, then, the content, the thought-element, and the words, were something outside poetry, and the poets must only take care of the form and verbal composition. The extraneousness of thoughts and

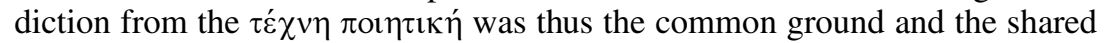
basic principle of all the крıєıкó. There were, however, some differences in the details. Heracleodorus (late third century B.C.E.) ${ }^{76}$ maintained that only euphony that supervenes upon word-order $(\sigma u ́ v \theta \varepsilon \sigma i \varsigma)$ mattered, whereas genre, style, and meter had nothing to do with poetry. ${ }^{77}$ In fact, according to him, even content was superflous: if the line sounded good, it did not matter if the verse was unintelligible. ${ }^{78}$ Similar but more extreme views were held by Pausimachus of Miletus (c. 200 B.C.E.), ${ }^{79}$ who considered sound the only source of poetic pleasure (that is, the sounds of vowels in particular),

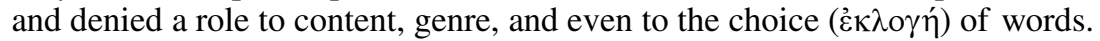
The first three views quoted in Zeno's list of Book 5 are along these lines: the first group calls for a "composition that delights the hearing or moves along beautifully and expresses the thought powerfully"; the second for a "verbal composition that signifies the underlying thought vividly and suggestively," and the third for a "composition that makes clear the underlying thought clearly and concisely along with preserving a poetic style." ${ }^{80}$ All these views focus on the verbal composition ( $\sigma u v v \theta \varepsilon \sigma 1 \varsigma)$, which is presented as the main task of a poet. The thought ( $\left.\delta \mathbf{t o ́}^{\mathrm{vol} \alpha} \alpha\right)$ is indeed there but its role is secondary; it is necessary only in the sense that poetry, qua poetry, must express something.

A particular case is represented by Crates, quoted by Philodemus among the крıлıкоí and considered the rival of Aristarchus in Homeric criticism. The assessment of the real nature of this opposition is still under debate. If, on the one hand, it is undeniable that Crates was in many respects pursuing a different kind of scholarship, more interested in the philosophical aspects of the text and in its allegorical meaning (especially in the light of Stoic cosmology), on the other hand the methodology he uses (etymology, attention to Homeric style, grammatical analysis, and even analogy) is largely shared

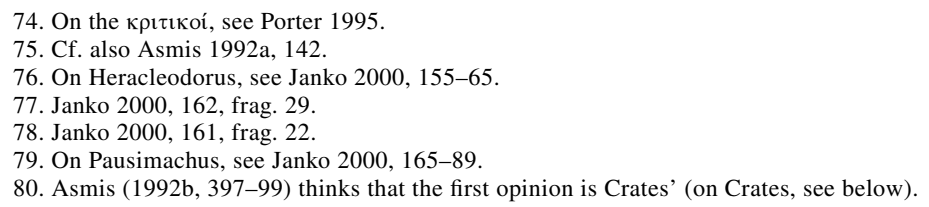


with the Alexandrians. Yet the similarity of methods used by these two schools highlights better their fundamentally different approaches to the topic, for there are frequent cases where Crates and Aristarchus use the same procedure (etymological analysis or even analogy) to reach opposite results. ${ }^{81}$

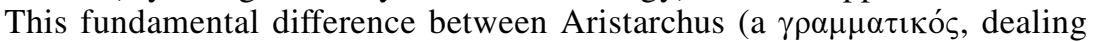

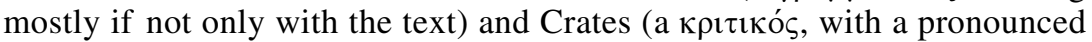
"philosophical" approach to Homer) was already recognized by Crates himself, who proudly maintained that he was able to "judge" a poem, unlike the grammarians concerned only with the limited analysis of words, syntax, and questions of authenticity (Sext. Emp. Math. 1.79):

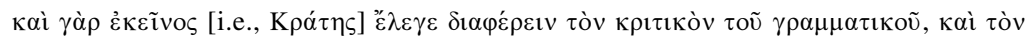

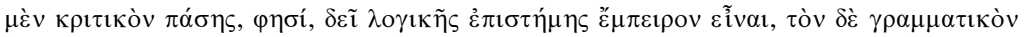

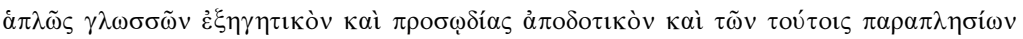

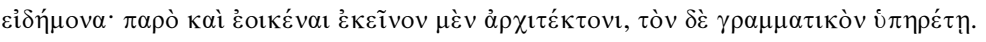

[Crates] said that the "critic" was better than the grammarian and that while the critic was experienced in all of logical science, the grammarian was simply an interpeter of rare words ( $g l \bar{s} s s a i)$, establisher of accents, and knower of things like these; hence the critic was like an architect and the grammarian like his servant. (Trans. Blank 1998) ${ }^{82}$

Further evidence of non-Aristotelian elements in Crates comes from Philodemus, On Poems, Book 5, cols. 24.25-29.18 Mangoni = frag. 101 Broggiato, where Philodemus dwells on Crates' view, and in particular from the following excerpts:

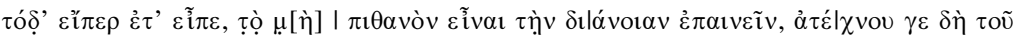

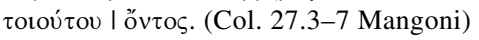

For he also said that it is not plausible to praise the thought, since this sort of thing is non-technical. (Trans. Asmis 1992a, 151)

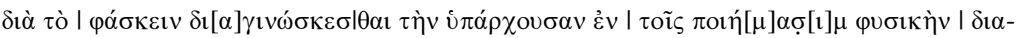

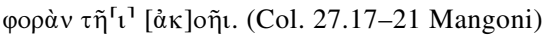

Because he claims that the natural difference that exists in poems is discerned by the hearing. (Trans. Asmis 1992a, 153)

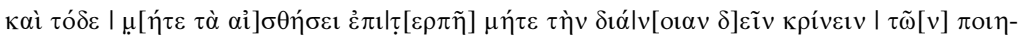

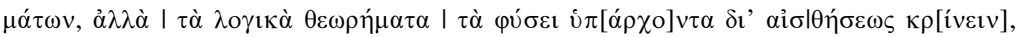

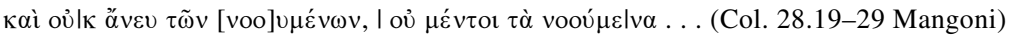

As to the claim that one must judge neither what is delightful to perception nor the thought of poems, but [one must] judge through perception the rational theorems that exist by nature, not without thoughts—not, however, the thoughts, . . . (Trans. Asmis 1992a, 155)

From these fragments, a major point in Crates' literary views emerges clearly. ${ }^{83}$ As for the крıтıкоí, for Crates too hearing alone can judge whether a poem is good or not. However, for Crates the judgment of euphony is not

81. On Crates and Stoicism, cf. Broggiato 2001, xxxi-xxxiii, lii, lvii-lviii, lx-lxi, lxiv-lxv; and Asmis 1992a, 139-40, 156-57, 161.

82. Cf. Blank 1998, 140-41; see also Broggiato 2001, 249-50 (on frag. 94).

83. See also Janko 2000, 122-23, esp. V 7, V 8, V 11. 
subjective, but happens on the basis of objective criteria that are recognized by the hearing. Also, whereas Heracleodorus and Pausimachus did not take the content into consideration at all, Crates allows for it, in the sense that

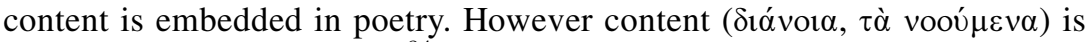
not the object of judgment. ${ }^{84}$ For $\delta$ tóvol $\alpha$ is a nontechnical (ä $\left.\tau \varepsilon \chi v o v\right)$ part of poetry. ${ }^{85}$

In sum, the constant and sole focus on $\sigma u ́ v \theta \varepsilon \sigma 1 \varsigma$ and $\varepsilon \dot{\varphi} \varphi \omega v^{\prime} \alpha^{86}$ as the only criteria to judge poetry, on the one hand, and the firm point that content and argument are outside the art, on the other, mark all these views as not Aristotelian $^{87}$ and also not Aristarchean. As we have seen, Aristarchus very often

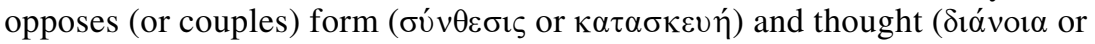
vó $\eta \mu \alpha$ ), as if they were the constitutive and polar parts of poetry, especially when giving reasons for an athetesis. If one decides on a line on the basis of the form or the thought-element (or both), obviously he considers these two elements as fundamental (and also technical) parts of the poetry, as did

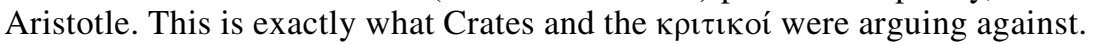

It is moreover interesting to note that the vocabulary adopted by the крıтนко and Crates is identical to that we find in Aristonicus' scholia, with terms like $\delta$ 'óvot $\alpha$, vớ $\mu \alpha \tau \alpha$, and $\sigma u ́ v \theta \varepsilon \sigma 1 \varsigma .{ }^{88}$ This means that we are dealing with technical terminology that indeed started first with the Peripatos and was fully developed during Hellenistic times and still used in the first century B.C.E. However, within this common terminology, the principles are radically dif-

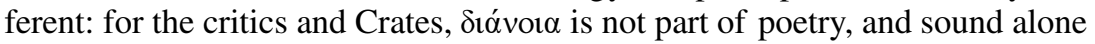
(either as verbal composition, $\sigma 0 ́ v \theta \varepsilon \sigma \iota \varsigma$, or as pure euphony) is the sole criterion by which to judge poetry. For Aristotle and Aristarchus the thought ( $\delta$ ióvora) — but we could speak more generally of content, including thus also the $\mu \tilde{v} \theta 0 \varsigma$ and the $\ddot{\eta} \theta \eta$-is at the core of poetry.

\subsection{Zeno's List: Theories on Diction ( $\sigma 0 ́ v \theta \varepsilon \sigma \iota \varsigma)$}

There is, however, more. In the list of Zeno, a second group of critics maintains that (Book 5, col. 30.6-10 Mangoni) the main point of a poem is a

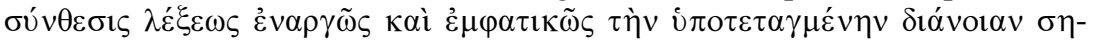
$\mu \alpha i ́ v o v \sigma \alpha$ ("a composition expressing the underlying thought vividly [ह่v $\alpha \rho \gamma \tilde{\omega} \varsigma]$

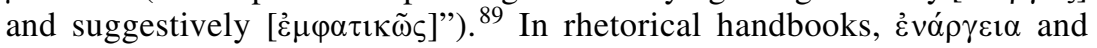

84. Cf. Asmis 1992a, 160: "Crates does not take the extremely radical position that what makes a poem good is simply the sound, considered apart from any meaning. . . His point, which is radical enough, is that what makes a poem good is the sound in relation to the meaning, regardless of what the meaning is."

85. Cf. Porter 1995, 93-99.

86. The theory of euphony stemmed from Pythagoras and the atomists and then was developed by the Stoics. Aristotle and the Alexandrians, however, rejected it; see Janko 2000, 173-82, 189.

87. Similar views are argued by Arrighetti (2001, 138-46).

88. For a full list of this technical terminology, overlapping with the Aristotelian one, see Mangoni 1993, 79-103.

89. On this opinion, see Asmis 1992b, 401-3. 'Е $\mu \varphi \alpha \tau 1 \kappa \tilde{\omega} \zeta$ is translated here with "suggestively," because $\varepsilon \varepsilon_{\mu} \mu \sigma \iota \varsigma$ in ancient literary criticisms does not correspond to the modern "emphasis," but is a technical term that indicates the ability that a poet has to express something that is not clearly stated, as Asmis (1992b, 402) explains: "There is no good English equivalent; 'suggestive' comes close in meaning. Although the term

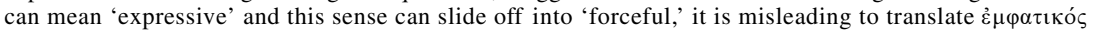
as 'emphatic' or 'forceful,' as it is often done." I have thus preferred to leave the Greek term "̌ $\mu \varphi \alpha \sigma i \varsigma$ instead of translating it into "suggestion," which may be equally confusing. 
$\varepsilon^{\prime} \mu \varphi \alpha \sigma ı$ are considered among the best qualities of style; ${ }^{90}$ this is in contrast with Aristotle, who maintains that the major virtue of style (both in prose and in poetry) is $\sigma \alpha \varphi \eta v v \varepsilon 1 \alpha .{ }^{91}$ We have seen that Aristarchus most highly praises

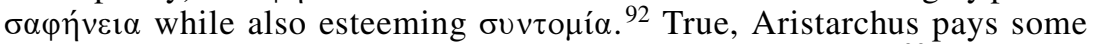
attention to Homer's ability to achieve $\alpha{ }^{\prime \prime} \xi \eta \sigma \iota \varsigma$ and ${ }^{\prime \prime} \mu \varphi \alpha \sigma \imath \varsigma,{ }^{93}$ but this is something that Aristotle as well admires in Homer (Rh. 1413b32-1414a7):

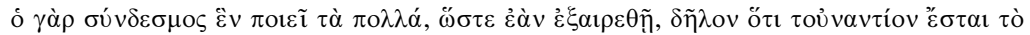

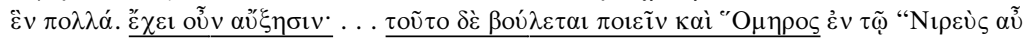

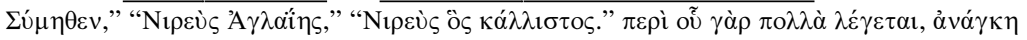

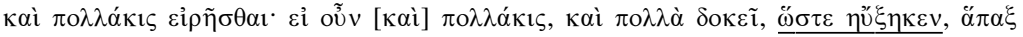

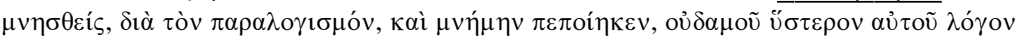

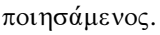

Just as the use of conjunctions makes many statements into a single one, so the omission of conjunctions acts in the reverse way and makes a single one into many. It thus makes everything more important... . This is the effect which Homer seeks when he writes "Nireus likewise from Syme, Nireus the son of Aglaia, Nireus, the comeliest man." If many things are said about a man, his name must be mentioned many times; and therefore people think that, if his name is mentioned many times, many things have been said about him. So that Homer, by means of this illusion, has made a great deal of Nireus, though he has mentioned him only in this one passage, and he has preserved his memory, though he nowhere says a word about him afterwards. (Trans. Roberts 1984)

It is interesting to note that the criterion of the $\dot{\varepsilon} v \alpha \rho \gamma \dot{\varepsilon} \varsigma$ seems to be absent from the scholia by Aristonicus. ${ }^{94}$ Moreover, the fact that those critics praised only the "excessive" qualities leading to amplification and $\varepsilon$ " $\mu \rho \alpha \iota \varsigma$ and did not pay any attention to clarity separates them from Aristotle and Aristarchus. ${ }^{95}$ The third opinion, instead, demands only clarity and concise-

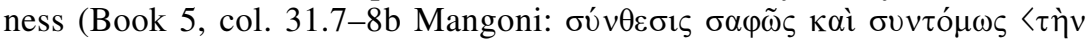

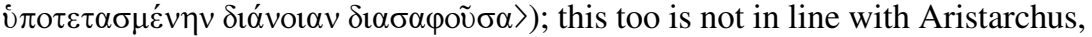
who recognized that Homer had a particular poetic manner of expression, for example with glossai, metaphors, and other figures of speech.

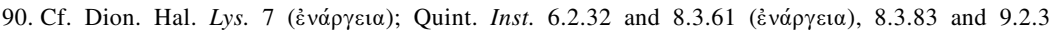

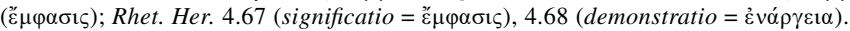

91. On Aristotle's virtues of diction, see Ax (1993, esp. 27-31), who outlines the virtues of diction

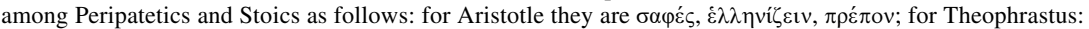

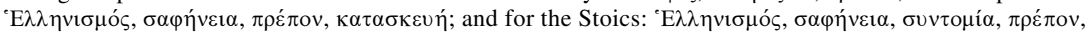

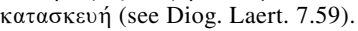

92. Cf. schol. Il. 1.110a, 3.352a, 8.108a, 8.528.

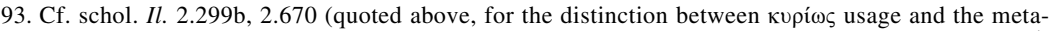
phorical one), 2.809, 3.80b, 6.169a, 8.108a, 9.44a, 15.470a, 15.622, 16.161a, 17.172, 23.16a, 24.6-9a ${ }^{1}$, $24.205 b^{1}$; cf. also Didymus in schol. Il. 19.386a. In another instance (schol. Il. 9.14b) Aristarchus was arguing that lines 15-16 of Book 9 of the Iliad, where Agamemnon is weeping "like a fountain of dark water that pours down murky water from a steep cliff" and that Zenodotus rejected, were instead $\alpha$ $v \alpha \gamma \kappa \alpha \tilde{\alpha} \alpha \delta \dot{\varepsilon}$. . .

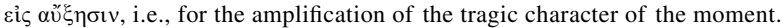

94. Out of forty-nine occurrences in the Iliad and Odyssey scholia of the words $\dot{\varepsilon} v \alpha \dot{\rho} \rho \varepsilon \varepsilon \alpha, \dot{\varepsilon} v \alpha \rho \gamma \varepsilon \dot{\varepsilon}$, and $\dot{\varepsilon} v \alpha \rho \gamma \tilde{\omega} \varsigma$, none goes back to Aristarchus. See also Zanker $(1981,307-8)$, who maintains that $\dot{\varepsilon} v \alpha \dot{\rho} \rho \varepsilon \varepsilon 1 \alpha$ is

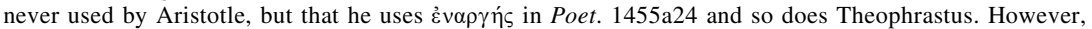
this is an Epicurean concept (ibid., 309-10).

95. According to Asmis (1992b, 405-6), the recognition that $\check{\varepsilon} \mu \varphi \alpha \sigma \iota \varsigma$ is the most important constituent of poetry leads to the adoption by Hellenistic scholars of allegorical reading, a way of reading poetry that was totally rejected by Aristarchus. 


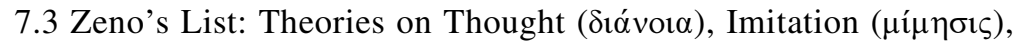 and More}

Of course, other Hellenistic theorists gave great importance to the thought

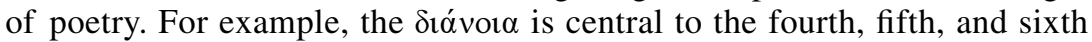
theories listed by Philodemus (himself a great supporter of the importance of the thought versus sound) in Book 5 of On Poems. ${ }^{96}$ Some (col. 31.33-

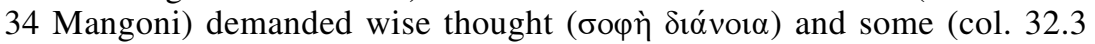

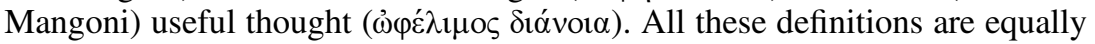
extraneous to Aristarchus, who never defines Homeric poetry as "useful" or remarks on the бopí $\alpha$ of the poet. This can be seen in conjunction with the idea that Homer does not aim at $\delta 1 \delta \alpha \sigma \kappa \alpha \lambda i \alpha$ but at $\psi v \chi \alpha \gamma \omega \gamma i \alpha$, a statement ascribed to Eratosthenes, who maintained that in Homer one should not look for any technical knowledge, geography in primis. ${ }^{97}$ This idea was shared by Aristarchus as well, and many are the scholia where, commenting on Homeric geography, Aristarchus claims that we do not have to seek for accuracy, or a true depiction of the cosmos. ${ }^{98}$

Then (col. 33.1-3 Mangoni) Philodemus mentions the opinion of those who call for a composition able to teach "something more" ( $\sigma u ́ v \theta \varepsilon \sigma ı v \lambda \varepsilon^{\prime} \xi$ -

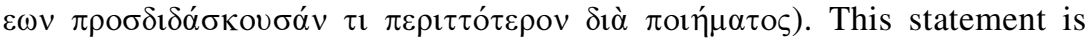
very interesting when compared with Aristarchean evidence, and not only because again it calls for a didactic aim in poetry. More importantly, $\pi \varepsilon \rho \sigma \sigma \sigma o ́ s$ and its derivatives are some of the most typical expressions to be found in the scholia of Aristonicus, but they are always used in a negative sense, meaning "superfluous." Everything that is $\pi \varepsilon \rho 1 \sigma \sigma o ́ v$ is rejected in Homer. Often this criterion is the deciding ground for an athetesis. ${ }^{99}$ This is a very interesting point because the negative sense for $\pi \varepsilon \rho 1 \sigma \sigma o ́ \varsigma$ (in itself a vox media, signifying "extraordinary" but also "superfluous," "useless") is shared with

96. See Asmis 1992b, 406-8.

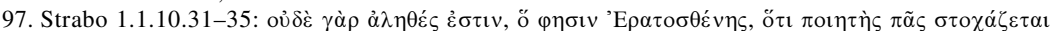

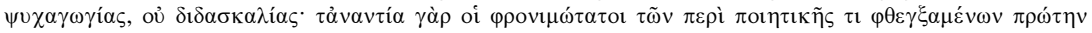

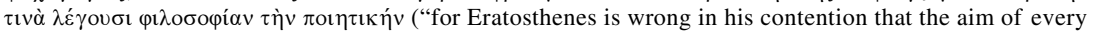
poet is to entertain, not to instruct; indeed the wisest of the writers on poetry say, on the contrary, that poetry is a kind of elementary philosophy," trans. Jones 1969). And also Strabo 1.2.3, in particular 1.2.3.37-

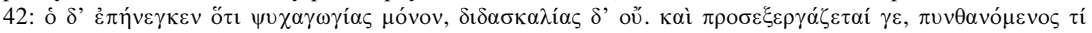

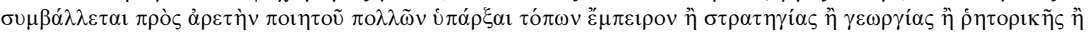

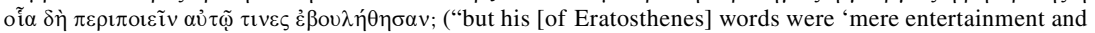
not instruction.' And Eratosthenes gives himself quite unnecessary pains when he asks how it contributes to the excellence of the poet for him to be an expert in geography, or in generalship, or in agriculture, or in rhetoric, or in any kind of special knowledge with which some people have wished to 'invest' him," trans. Jones 1969).

98. Cf., for example, Aristarchus' criticism of those (like Crates; cf. Strabo 3.4.4.1-15 (= frag. 75 Broggiato) who interpreted the voyages of Odysseus as a true geographical decription of the oikov $\mu \varepsilon \dot{v} \eta$

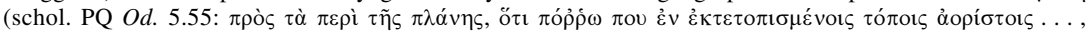

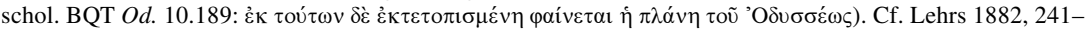
46; Buonajuto 1996. The link between $\psi v \chi \alpha \gamma \omega \gamma i$ í and poetry is present in Aristotle too (Poet. 1450a33-

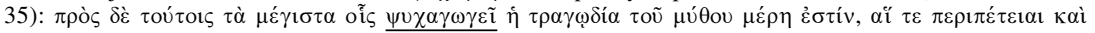

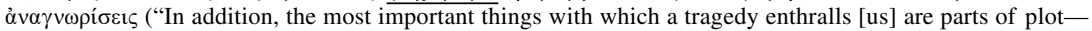
reversals and recognitions," trans. Janko 1987). Here however the point is not so much about the goals of poetry but rather about the means by which the $\psi v \chi \alpha \gamma \omega \gamma i \alpha$ is achieved. Hence, the parallel between Aristotle and the two Alexandrians is not so close.

99. On this topic, see Lührs 1992. 
Aristotle. The philosopher, especially in his works on biology, sees nature

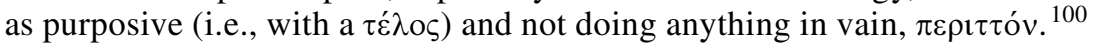
The same is, according to Aristarchus, the pú theorists quoted by Philodemus demand a poet who teaches us something $\pi \varepsilon \rho \iota \tau \tau$ ó $\varepsilon \rho \circ \mathrm{v}$, where the adjective is obviously used in a positive meaning, incompatible with the meaning that this key concept has for Aristarchus throughout our sources.

The seventh view in Zeno's list calls for the mimesis of other poets. ${ }^{101}$ This is one of the bases of Roman literature, and we have no earlier evidence for it apart from this hint in Philodemus. To present Homer as a model that must be imitated can indeed be seen as a development of Aristotle's view of Homer as a master of the craft and of Aristarchus' distinction

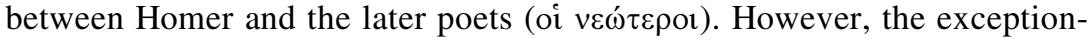
ality of Homer compared to all other poets is so deep according to Aristarchus that a mimesis is virtually impossible: the $v \varepsilon \omega \tau \tau \varepsilon \rho o$ can only try to imitate "the poet" but their results are so openly inferior that Aristarchus cannot but notice their bad outcome. In the Aristarchean scholia the

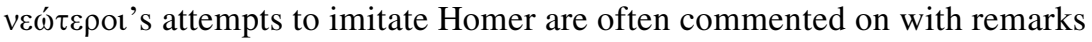
like $\dot{\varepsilon} \pi \lambda \alpha v \eta \dot{\theta} \mid \bar{\varepsilon} \pi \lambda \alpha v \eta \dot{\theta} \theta \eta \sigma \alpha \nu$, "he was/they were misled," that is, he/they missed the point, he/they got it wrong. ${ }^{102}$

The other opinions (8-13) are extremely generic, and therefore they cannot be referred back to any particular school. ${ }^{103}$ The opinions, which

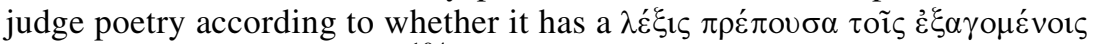
$\pi \rho 0 \sigma \omega ́ \pi$ or (eighth opinion), ${ }^{104}$ or on the basis of its effects on the audience (ninth and tenth opinions), of its beauty (eleventh opinion), of its goodness (twelfth opinion), or of $\pi \rho \varepsilon ́ \pi$ ov (thirteenth opinion) are not comprehensive

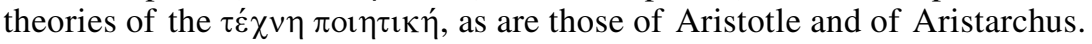
For those about whom we know more, however, the крєєєкоi and Crates, the points of discrepancy are so many that the affinity between Aristarchus and Aristotle becomes even more evident.

\subsection{The Peripatetics: Neoptolemus of Parium, Heraclides of Pontus, Andromenides, and Megaclides of Athens}

Among Hellenistic scholars dealing with poetry, Neoptolemus of Parium shows an interesting overlap with the views we have found in Aristotle and Aristarchus. ${ }^{105}$ Neoptolemus was a Peripatetic living in the third century B.C.E., whose work is entirely lost and can be recovered mainly (again) through Philodemus On Poems 5 (cols. 13.32-16.28 Mangoni). ${ }^{106}$ As is well known, Neoptolemus divided the art of poetry into three parts: the poet

100. See von Staden 1997.

101. See Asmis 1992b, 408-10.

102. Cf. schol. Il. 2.659, 4.439-40, 14.500, 15.119. On the neoteroi, cf. Severyns 1928. For an example, see Aristarchus' criticism of Antimachus in Schironi 1999.

103. See Asmis 1992b, 410-14.

104. This is from Andromenides (see p. 312 below); cf. Janko 2000, 147, F 8.

105. Cf. Asmis 1992c.

106. Cf. Brink (1963, 145-49), who calls Neoptolemus' approach a "revised Aristotelianism"; and Janko 2000, 152. The fragments of Neoptolemus are collected by Mette (1980). 


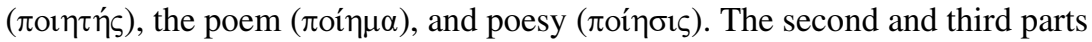

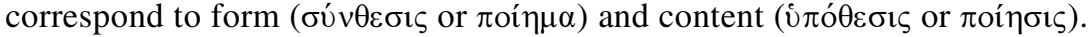
This opposition $\sigma u ́ v \theta \varepsilon \sigma ı / \imath \pi$ ó $\theta \varepsilon \sigma ı \varsigma$ as outlined by Neoptolemus (he himself

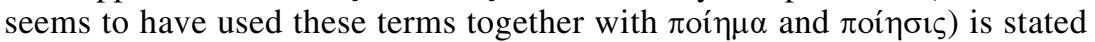
in Book 5 (col. 14.26-28 Mangoni):

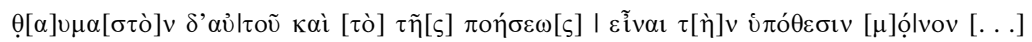

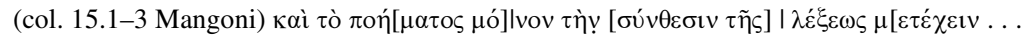

It is astonishing of him to claim that only theme belongs to poiesis. . . Also, [it is astonishing] that only verbal composition [participates] in a "poem." ... (Trans. Asmis 1992c, 210)

The technical terminology is the usual one; however, a link between Neoptolemus and the Alexandrians can be seen in the opposition between form and content as expressed with $\sigma u ́ v \theta \varepsilon \sigma \iota \varsigma / i ́ \pi$ ó $\theta \varepsilon \sigma \iota \varsigma$. We have already mentioned the vast usage of the term $\sigma u v \theta \varepsilon \sigma i \varsigma$ to indicate "composition," "style," among the Alexandrians. This terminology is actually missing in Aristotle who, as was observed, used instead $\lambda \varepsilon^{\prime} \xi_{1 \zeta}$ to indicate "form" and "style." It seems as if the usage of $\sigma u ́ v \theta \varepsilon \sigma ı \varsigma$ for "form" (in opposition, even from a morphological point of view, to $i \pi$ ó $\theta \varepsilon \sigma 1 \varsigma$ for the "content") is a later development, which might have been due to Neoptolemus himself. ${ }^{107}$ This Peripatetic scholar, like Aristotle and Demetrius of Phalerum before him, was known at Alexandria ${ }^{108}$ and exercised some sort of influence among the $\gamma \rho \alpha \mu \mu \alpha \tau \iota \kappa o$ there. While in the scholia derived from Aristarchus there seems to be no trace of the opposition $\sigma u ́ v \theta \varepsilon \sigma \iota \varsigma /$ i $\pi$ ó $\theta \varepsilon \sigma \iota \varsigma$ as formulated by Neoptolemus, the use of the word $i \pi$ ó $\theta \varepsilon \sigma \iota \varsigma$ to indicate the "content" of a literary work comes from Aristophanes of Byzantium, who used the term to refer to the summaries of the "content" of the dramas. However, apart from this idea of poetry as based on form and content, the tripartite division of poetry as devised by Neoptolemus is absent in Aristarchus as well as in Aristotle. ${ }^{109}$ Also different is the idea that the poets, according to Neoptolemus, should both delight and benefit, a criterion that seems closer to Plato than to Aristotle. ${ }^{110}$ The importance of $\delta 1 \delta \alpha \sigma \kappa \alpha \lambda i$ is as the goal of poetry had already been advocated by Heraclides of Pontus (fourth century B.C.E.), a pupil of Plato and Aristotle, ${ }^{111}$ who, besides writing "grammatical" treatises on Homer and other poets in the best Aristotelian tradition, maintained, more in line with the euphonistic school, that $\dot{\varepsilon} \mu \mu \varepsilon \dot{\varepsilon} \varepsilon \varepsilon \alpha$, "musicality" and

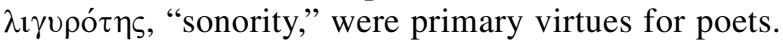

Andromenides (third century B.C.E.?) is perhaps the closest to Aristotle and Aristarchus. His case, like that of Heraclides, is interesting evidence of how the Hellenistic critics were influenced by many different doctrines.

107. See Schironi, in Bottai and Schironi 1997, 1058-62.

108. He was quoted by Aristophanes of Byzantium in his glossographical works. This, however, does not mean that Neoptolemus was indeed working at Alexandria, a hypothesis supported by Mette (1935, esp. 2467). For a more cautious view on the relationship between Neoptolemus and the Alexandrian scholars, see Brink 1963, 135-50.

109. See Asmis 1992c, where she tries to find other traces of this theory in rhetorical treatises.

110. See Asmis 1992c, 218.

111. On Heraclides, see Janko 2000, 134-38. 
Philodemus in Book 1 quotes him among the крıєıкоí; ${ }^{112}$ however, he has many views in common with Neoptolemus of Parium. Like Neoptolemus and the Peripatetic tradition, he collected glosses. Moreover, he seems to

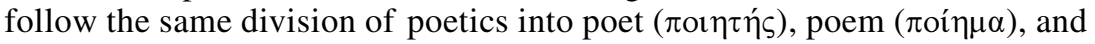

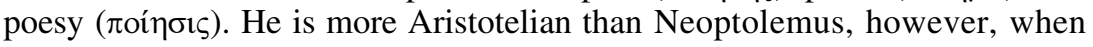
he maintains that poetry aims to please (and not to impart truth like prose) and when he holds the view that each genre has its own subject matter and

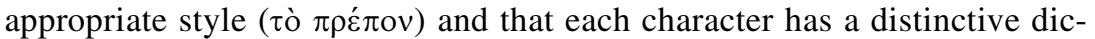
tion. On the other hand, Andromenides, like Crates, maintained that the ear

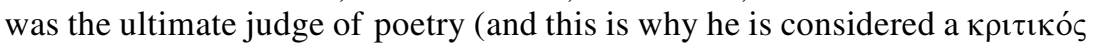
by Philodemus), and also that diction and word choice ( $\dot{\kappa} \kappa \circ \gamma \eta \dot{n})$ were paramount. This emphasis on phonetic beauty, not so prominent in Aristotle, is at the core of Theophrastus' theory of style ${ }^{113}$ and can be seen as a later development of the Peripatetic school.

The case of Megaclides (early third century B.C.E.) is similar; he, while

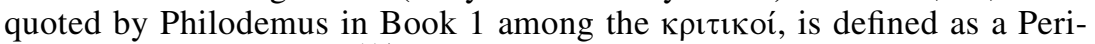

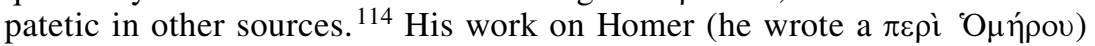
and on his language (he believed that Homeric dialect was Attic, like Aristarchus) is purely in line with Alexandrian interests. Moreover, his distinction, especially in terms of mythological tradition, between Homer and Hesiod, on the one hand, and post-Homeric and post-Hesiodic poets, on the other, makes him an Aristotelian with ideas very close to those of Aristarchus. However, he was listed by Crates among the advocates of the ear (and not the intellect) as the best judge for poetry. And even if his precise poetical theories are still under debate, due to the fragmentary state of the evidence from On Poems 1, he seems to be close to Heraclides of Pontus and Andromenides, as Janko has concluded. ${ }^{115}$ The euphonistic approach to literature shared by all these Peripatetic scholars makes them pupils more of

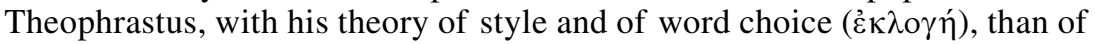
Aristotle, with his content-based approach to texts.

\section{CONCLUSION}

As I hope to have shown, Aristarchus seems to have been aware of Aristotelian reflections on poetry. In his work on Homer, he uses Aristotelian categories and critical concepts. This is particularly evident when Aristarchus has to deal with atheteses or argues against Zenodotus' readings. Interesting similarities between Aristotle and Aristarchus are to be found in the handling of the plot (it can contain "impossible elements," but they must be "according to necessity or probability"), of the characters (they are of necessity "serious" and their behavior must be according to what is considered "proper"), of the thought-element (epos is a serious genre, hence all the comic elements must

112. On Andromenides, see Janko 2000, 143-54.

113. Cf. Dion. Hal. Isoc. 3.1; and Ardizzoni 1953, 70-72.

114. Frag. 2 Janko. On Megaclides, see Janko 2000, 138-43.

115. Cf. Janko 2000, 143. 
be avoided) and of style (which must be clear, but also poetic, i.e. rich in glosses and metaphors).

The affinity between Aristotle and Aristarchus is further proved by a comparison with other Hellenistic views on poetry. Here, while the technical vocabulary is almost identical, the views held by Crates or the other Hellenistic крıєıкоí are opposite or, at best, far in spirit from what was expressed by Aristotle. In particular, their continuous focus on the sound-element and euphony against content are in striking opposition to Aristotle's theory and Aristarchus' practice. ${ }^{116}$

There is, however, a fundamental distinction between Aristotle and Aristarchus: whereas the philosopher theorizes these principles, the philologist applies them. In this, Aristarchus is different from colleagues like Crates

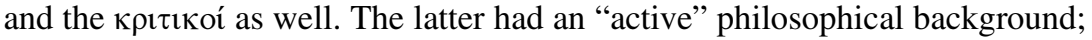
they claimed to be critics because they aimed to give prescriptive views on how one should write a poem. Aristarchus does not claim anything like that, but tries to make a better text of Homer by editing and commenting on it. In this sense, Aristarchus (and his Alexandrian predecessors) are different from all the other scholars who were taken into account, who like Crates (and, in this view, Aristotle too) wanted to develop theories out of the study of Homer. For Aristarchus, Aristotelian philosophy, like grammatical categories, is, instead, just a tool to use in his job: working on texts, preparing editions and writing commentaries. The contrast could not be greater: on the one hand, literary critics like Crates and the other крıєıко', having a particular agenda, or, as in the case of Crates, influenced by Hellenistic philosophy, versus grammarians like Aristarchus, on the other. The latter had a "scientific approach" to the text, looking at the bare data on the basis of a very clear account: that of Aristotle, the founder of scientific inquiry.

Harvard University

116. I am not arguing that Aristotelian concepts are present only in Aristarchean scholia. As Richardson (1980) has demonstrated, they are abundantly present in the exegetical scholia. For example, in schol.

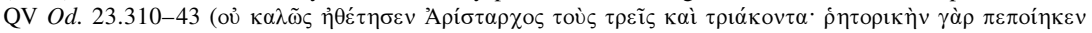

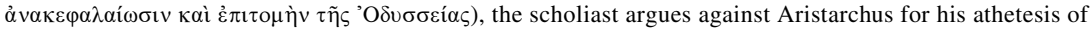

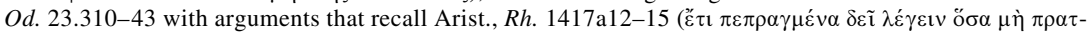

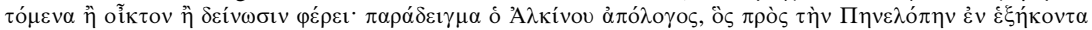

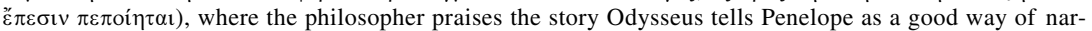
rating a story cutting off all the most terrifying details. However, my claim here is that, even if we find more Aristotelian concepts in the exegetical scholia (which are a product of later scholarship), we do find Aristotelian concepts even in Aristarchus, and in opposition to the other Hellenistic theorists. 
APPENDIX

Aristotle and Aristarchus on the Four Parts of Epic Poetry

\begin{tabular}{|c|c|c|}
\hline & Aristotle & Aristarchus \\
\hline \multirow[t]{5}{*}{ Mũ $\theta$ os } & 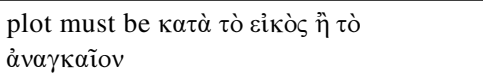 & \\
\hline & $\begin{array}{l}\alpha \delta v^{\prime} \alpha \tau \alpha \text { are allowed in poetry for the } \\
\text { sake of } \tau \text { ò } \theta \alpha u \mu \alpha \sigma \tau \text { óv }\end{array}$ & 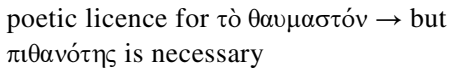 \\
\hline & 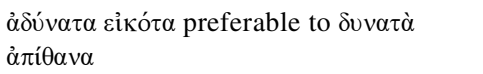 & \\
\hline & 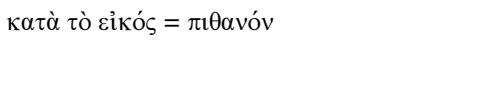 & 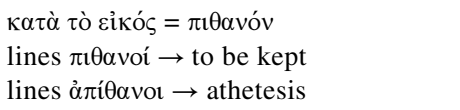 \\
\hline & $\begin{array}{l}\text { against internal inconsistencies } \\
(\text { i } \pi \varepsilon v \alpha v \tau i ́ \alpha)\end{array}$ & $\begin{array}{l}\text { what is } \alpha \sigma v \mu \varphi \omega ́ v \omega \varsigma \text { or } \mu \alpha \alpha^{\prime} \varepsilon \tau \alpha \mathrm{l} \text { with the } \\
\text { rest is rejected }\end{array}$ \\
\hline \multirow[t]{2}{*}{ "H $\mathrm{H} \theta \eta$} & 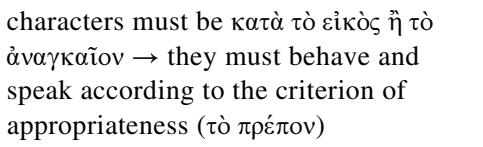 & 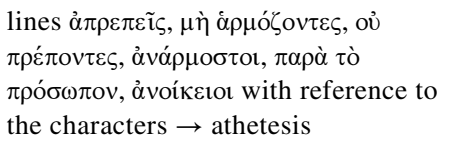 \\
\hline & $\begin{array}{l}\text { character differences include age, sex, } \\
\text { nationality, etc. }\end{array}$ & $\begin{array}{l}\text { behavior codes for heroes, women, old } \\
\text { and young people, Greeks, and } \\
\text { barbarians, et al. }\end{array}$ \\
\hline 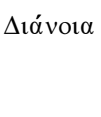 & 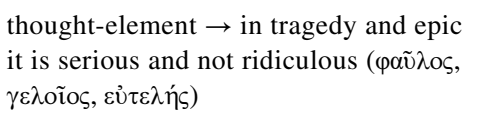 & $\begin{array}{l}\text { lines } \gamma \varepsilon \lambda \text { oĩot, } \varepsilon \cup ̉ \tau \varepsilon \lambda \varepsilon \tilde{i} \varsigma \tau \tilde{\eta} \text { } \delta ı \alpha \text { oí } \alpha \rightarrow \\
\text { athetesis }\end{array}$ \\
\hline \multirow[t]{5}{*}{$\Lambda \varepsilon^{\prime} \xi_{1 \zeta}$} & $\begin{array}{l}\text { poetic diction must be clear and not } \\
\text { commonplace }\end{array}$ & \\
\hline & $\begin{array}{l}\sigma \alpha \varphi \eta ́ v \varepsilon 1 \alpha \text { is achieved through the use of } \\
\kappa \cup ́ \rho 1 \alpha \text { ỏvó } \mu \alpha \tau \alpha\end{array}$ & 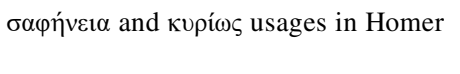 \\
\hline & 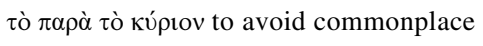 & oủ kupí $\omega \varsigma$ usages in Homer \\
\hline & $\begin{array}{l}\text { Rhetoric: language must not be } \\
\text { "poetical" in prose }\end{array}$ & language must not be prosaic in poetry \\
\hline & Rhetoric: against $\varepsilon^{\prime} \pi i \theta \varepsilon \tau \alpha \stackrel{\alpha}{\alpha} \kappa \alpha \iota \alpha$ & $\dot{\varepsilon} \pi i \theta \varepsilon \tau \alpha \stackrel{\alpha}{\alpha} \alpha \_\rho \rightarrow$ athetesis \\
\hline
\end{tabular}




\section{LITERATURE CITED}

Ardizzoni, A. 1953. Пoí $\mu \alpha$ : Ricerche sulla teoria del linguaggio poetico nell'antichità. Bari. Arrighetti, G. 2001. Filodemo, Lucrezio e le poetiche dell'Ellenismo. WürzJbb, n.s., 25: 133-55.

Asmis, E. 1992a. Crates on Poetic Criticism. Phoenix 46: 138-69. 1992b. An Epicurean Survey of Poetic Theories. CQ 42: 395-415. 1992c. Neoptolemus and the Classification of Poetry. CP 87: 206-31.

Ax, W. 1993. Der Einfluß des Peripatos auf die Sprachtheorie der Stoa. In Dialektiker und Stoiker, Zur Logik der Stoa und ihrer Vorläufer, ed. K. Döring and T. Ebert, 11-32. Stuttgart.

Barnes, J. 1999. Roman Aristotle. In Philosophia Togata: Plato and Aristotle at Rome, ed. J. Barnes and M. Griffin, vol. 2, 1-69. Oxford.

Blank, D. 1998. Sextus Empiricus, "Against the Grammarians (Adversus mathematicos I)." Translated with introduction and commentary. Oxford.

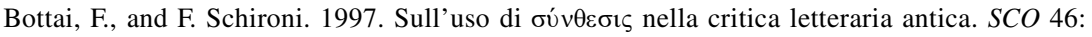
1049-77.

Brink, O. 1963. Horace on Poetry: Prolegomena to the Literary Epistles. Cambridge.

Broggiato, M. 2001. Cratete di Mallo. I frammenti. Edizione, introduzione e note. La Spezia.

Buonajuto, A. 1996. L'E $\Xi \Omega K E A N I \Sigma M O \Sigma$ dei viaggi di Odisseo in Cratete e negli Alessandrini. AeR 41: 1-8.

Canfora, L. 1988. La biblioteca scomparsa. Palermo.

2002. Aristotele "fondatore" della Biblioteca di Alessandria. In Scritti in onore di Italo Gallo, ed. L. Torraca. Pubblicazioni dell'Università degli Studi di Salerno. Sezione atti convegni miscellanee 59, 167-75. Naples.

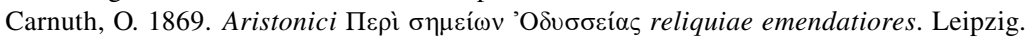

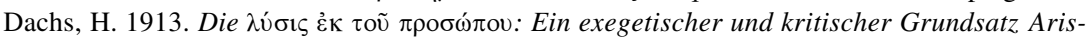
tarchs und seine Neuanwendung auf "Ilias" und "Odyssee." Inaugural Dissertation. Erlangen.

Erbse, H. 1972. Beiträge zum Verständnis der "Odyssee." Berlin.

Gallavotti, C. 1969. Tracce della Poetica di Aristotele negli scoli omerici. Maia 21: 203-14.

Janko, R. 1982. A Fragment of Aristotle's Poetics from Porphyry, concerning Synonymy. $C Q$, n.s., 32: 323-26.

1987. Aristotle "Poetics" I, with the "Tractatus Coislinianus," Recontruction of "Poetics" II, and the Fragments of the "On Poets." Indianapolis.

1991. Philodemus' On Poems and Aristotle's On Poets. CronErcol 21: 5-64.

2000. Philodemus, "On Poems," Book One. Edited with introduction, translation, and commentary, Oxford.

Jenkins, T. 1999. Homêros ekainopoiêse: Theseus, Aithra, and Variation in Homeric MythMaking. In Nine Essays on Homer, ed. M. Carlisle and O. Levaniouk, 207-26. Lanham, Md.

Jones, H. 1969. The Geography of Strabo. Vol. 1. London.

Lehrs, K. 1882. De Aristarchi Studiis Homericis ${ }^{3}$. Leipzig.

Lührs, D. 1992. Untersuchungen zu den Athetesen Aristarchs in der "Ilias" und zu ihrer Behandlung im Corpus der exegetischen Scholien. Hildesheim.

Mangoni, C. 1993. Il quinto libro della "Poetica" (P. Herc. 1425 e 1538). Naples.

Matthaios, S. 1996. Kúpiov óvopa. Zur Geschichte eines grammatischen Terminus. In Ancient Grammar: Content and Context, ed. P. Swiggers and A. Wouters, 55-77. Leuven.

1999. Untersuchungen zur Grammatik Aristarchs: Texte und Interpretation zur Wortartenlehre. Hypomnemata 126. Göttingen.

2002. Neue Perspektiven für die Historiographie der antiken Grammatik: Das

Wortartensystem der Alexandriner. In Grammatical Theory and Philosophy of Language in Antiquity, ed. P. Swigger and A. Wouters, 161-220, Leuven.

Mette, J. 1935. Neoptolemus (11). RE 32: 2465-70.

1980. Neoptolemos von Parion. RhM 123: 1-24. 
Montanari, F. 1993. L'erudizione, la filologia e la grammatica. In Lo spazio letterario della Grecia antica, ed. G. Cambiano, L. Canfora, and D. Lanza, 1.2: 235-81. Rome.

—, ed. 1994. La philologie grecque à l'époque hellénistique et romaine. Entretiens sur l'Antiquité classique 40. Geneva.

1995. Termini e concetti della Poetica di Aristotele in uno scolio a Odissea IV 69. In Studi di filologia omerica antica, vol. 2, 21-25. Pisa.

2001. Gli studi omerici di Demetrio Falereo. SemRom 4: 143-57.

Moraux, P. 1973. Der Aristotelismus bei den Griechen: Von Andronikos bis Alexander von Aphrodisia. Vol. 1. Berlin.

Nagy, G. 1998. The Library of Pergamon as a Classical Model. In Pergamon: Citadel of the Gods, ed. H. Koester. Harvard Theological Studies 46, 185-232. Harrisburg, Pa.

Nickau, K. 1977. Untersuchungen zur textkritischen Methode des Zenodotos von Ephesos. Berlin.

Pfeiffer, R. 1968. History of Classical Scholarship. Vol. 1, From the Beginnings to the End of the Hellenistic Age. Oxford.

Podlecki, A. 1969. The Peripatetics as Literary Critics. Phoenix 23: 114-37.

Porter, J. 1992. Hermeneutic Lines and Circles: Aristarchus and Crates on the Exegesis of Homer. In Homer's Ancient Readers: The Hermeneutics of Greek Epic's Earliest Exegetes, ed. R. Lamberton and J. J. Keaney, 67-114. Princeton, N.J.

. 1995. Oi крıєєкоí: A Reassessment. In Greek Literary Theory after Aristotle, ed. J. G. J. Abbenes, S. R. Slings, and I. Sluiter, 83-109. Amsterdam.

Richardson, N. 1980. Literary Criticism in the Exegetical Scholia to the Iliad: A Sketch. $C Q$, n.s., 30: 265-87.

1992. Aristotle's Reading of Homer and Its Background. In Homer's Ancient Readers: The Hermeneutics of Greek Epic's Earliest Exegetes, ed. R. Lamberton and J. J. Keaney, 30-40. Princeton, N.J.

1993. The "Iliad": A Commentary. Vol. VI, Books 21-24. Cambridge.

1994. Aristotle and Hellenistic Scholarship. In Montanari 1994, 7-38.

Roberts, W. Rhys. 1984. Rhetoric. In The Complete Works of Aristotle. The Revised Oxford Translation, ed. J. Barnes, vol. 2, 2152-2269. Princeton, N.J.

Rossi, L. E. 1976. Umanesimo e filologia (a proposito della Storia della filologia classica di Rudolf Pfeiffer). RivFil 104: 98-117.

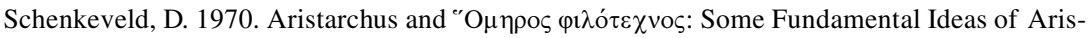
tarchus on Homer as a Poet. Mnemosyne 23: 162-78.

Schironi, F. 1999. Aristarco studioso di Antimaco. RivFil 127: 282-90.

Schmidt, M. 1976. Die Erklärungen zum Weltbild Homers und zur Kultur der Heroenzeit in den bT-Scholien zur "Ilias." Munich.

Severyns, A. 1928. Le cycle épique dans l'école d'Aristarque. Liège.

Staden, H. von. 1997. Teleology and Mechanism: Aristotelian Biology and Early Hellenistic Medicine. In Aristotelische Biologie: Intentionen, Methoden, Ergebnisse. Akten des Symposions über Aristoteles' Biologie vom 24.-28. Juli 1995 in der Werner-Reimers-Stiftung in Bad Homburg, ed. W. Kullmann and S. Föllinger, 183-208. Stuttgart.

Zanker, G. 1981. Enargeia in the Ancient Criticism of Poetry. RhM 124: 297-311. 